\title{
Role of vegetation change in future climate under the A1B scenario and a climate stabilisation scenario, using the HadCM3C Earth system model
}

\author{
P. D. Falloon ${ }^{1}$, R. Dankers ${ }^{1}$, R. A. Betts ${ }^{1}$, C. D. Jones ${ }^{1}$, B. B. B. Booth ${ }^{1}$, and F. H. Lambert ${ }^{2}$ \\ ${ }^{1}$ Met Office Hadley Centre, Fitzroy Road, Exeter, Devon EX1 3PB, UK \\ ${ }^{2}$ College of Engineering, Mathematics and Physical Sciences, University of Exeter, Harrison Building, North Park Road, \\ Exeter, EX4 4QF, UK
}

Correspondence to: P. D. Falloon (pete.falloon@metoffice.gov.uk)

Received: 24 May 2012 - Published in Biogeosciences Discuss.: 25 June 2012

Revised: 28 October 2012 - Accepted: 2 November 2012 - Published: 23 November 2012

\begin{abstract}
The aim of our study was to use the coupled climate-carbon cycle model HadCM3C to quantify climate impact of ecosystem changes over recent decades and under future scenarios, due to changes in both atmospheric $\mathrm{CO}_{2}$ and surface albedo. We use two future scenarios - the IPCC SRES A1B scenario, and a climate stabilisation scenario (2C20), allowing us to assess the impact of climate mitigation on results. We performed a pair of simulations under each scenario - one in which vegetation was fixed at the initial state and one in which vegetation changes dynamically in response to climate change, as determined by the interactive vegetation model within HadCM3C.

In our simulations with interactive vegetation, relatively small changes in global vegetation coverage were found, mainly dominated by increases in shrub and needleleaf trees at high latitudes and losses of broadleaf trees and grasses across the Amazon. Globally this led to a loss of terrestrial carbon, mainly from the soil. Global changes in carbon storage were related to the regional losses from the Amazon and gains at high latitude. Regional differences in carbon storage between the two scenarios were largely driven by the balance between warming-enhanced decomposition and altered vegetation growth. Globally, interactive vegetation reduced albedo acting to enhance albedo changes due to climate change. This was mainly related to the darker land surface over high latitudes (due to vegetation expansion, particularly during December-January and March-May); small increases in albedo occurred over the Amazon. As a result,
\end{abstract}

there was a relatively small impact of vegetation change on most global annual mean climate variables, which was generally greater under $\mathrm{A} 1 \mathrm{~B}$ than $2 \mathrm{C} 20$, with markedly stronger local-to-regional and seasonal impacts. Globally, vegetation change amplified future annual temperature increases by 0.24 and $0.15 \mathrm{~K}$ (under $\mathrm{A} 1 \mathrm{~B}$ and $2 \mathrm{C} 20$, respectively) and increased global precipitation, with reductions in precipitation over the Amazon and increases over high latitudes. In general, changes were stronger over land - for example, global temperature changes due to interactive vegetation of 0.43 and $0.28 \mathrm{~K}$ under $\mathrm{A} 1 \mathrm{~B}$ and $2 \mathrm{C} 20$, respectively. Regionally, the warming influence of future vegetation change in our simulations was driven by the balance between driving factors. For instance, reduced tree cover over the Amazon reduced evaporation (particularly during June-August), outweighing the cooling influence of any small albedo changes. In contrast, at high latitudes the warming impact of reduced albedo (particularly during December-February and March-May) due to increased vegetation cover appears to have offset any cooling due to small evaporation increases.

Climate mitigation generally reduced the impact of vegetation change on future global and regional climate in our simulations. Our study therefore suggests that there is a need to consider both biogeochemical and biophysical effects in climate adaptation and mitigation decision making. 


\section{Introduction}

Major changes in future global ecosystem distribution are projected, particularly for two key regions: the Amazon and high latitudes. In response to future climate change, most stand-alone dynamic global vegetation models (DGVMs: Sitch et al., 2008) and the coupled climate-carbon cycle general circulation models (GCMs) that include DGVMs in their formulation (Cox et al., 2000; Friedlingstein et al., 2006) tend to simulate varying degrees of loss in the tree plant functional type (PFT) cover over the Amazon, and gains in woody cover in the tundra, while some models suggest losses of herbaceous vegetation in the tundra and others gains, or no change.

These changes in land cover patterns may have considerable impacts on the climate (Desjardins et al., 2007), both through modifying the physical properties of the land surface (biophysical effects) and by altering the absorption or emission of greenhouse gases (biogeochemical forcings).

\subsection{Biogeochemical impacts of land cover change on climate}

Biogeochemical forcings due to land cover change include changes in greenhouse gas (GHG) fluxes - for instance changes in soil and vegetation carbon storage, carbon dioxide fluxes, changes in emissions of nitrous oxide and methane (Paustian et al., 2006), and changes in water vapour, which may have a global effect due to their impact on longwave radiation. Regionally, most stand-alone and coupled DGVMs simulate a reduction in vegetation carbon over Amazonia and increases in vegetation carbon over tundra ecosystems. There is less agreement in simulated changes in soil carbon stocks - at high latitudes responses vary from large and small increases to a strong decrease; some models project strong decreases over Amazonia and others a small increase (Sitch et al., 2008; Friedlingstein et al., 2006) .

\subsection{Biophysical impacts of land cover change on climate}

The biophysical impacts of changes in land cover may alter local surface fluxes of radiation (e.g. albedo), heat, moisture (e.g. evaporation) and momentum (e.g. roughness length), which in turn may alter local, regional, and to some extent global climates (Lean and Warrilow, 1989; Pielke et al., 1998; Betts, 2001, 2005; Feddema et al., 2001; Betts et al., 2007; Raddatz, 2007; Pongratz et al., 2010). The relative importance of these processes depends on local conditions such as the underlying surface albedo and soil moisture availability, and can vary with season and location (Betts, 1999; Betts et al., 2007).

Overall, deforestation in high-latitude regions may lead to a cooling under present climate due to the dominant effect of increased surface albedo and increased shortwave reflection (Thomas and Rowntree, 1992; Bonan et al., 1992; Foley et al., 1994; Douville and Royer, 1997; Betts, 1999, 2001; Bounoua et al., 2002; Davin and De Noblet-Ducoudre, 2010; Lee et al., 2011). Conversely, increases in cool-region forest area may have the opposite effect. However, recent studies have questioned whether warming resulting from large-scale mid- and high latitude afforestation may be altered by enhanced transpiration (Swann et al., 2010) and water vapour export (Swann et al., 2011), which may trigger further feedbacks and alter circulation patterns. Tropical deforestation is expected to lead to a warming and drying of local climate since the impact of reduced evapotranspiration (Lean and Warrilow, 1989; Betts et al., 2007; Wang and Davidson, 2007; Davin and De Noblet-Ducoudre, 2010) may outweigh the relatively small changes in albedo. Future Amazon forest losses due to climate change may therefore contribute to further warming. In addition, the biogeophysical effects of the projected future climate-driven Amazon forest dieback may also be important locally, acting to further reduce rainfall (Betts et al., 2004). On the other hand, the projected future increases in high latitude forest area and productivity may warm future climate due to reduced surface albedo (Betts, 2000), particularly during December-February and MarchMay (Betts et al., 2007).

\subsection{Present study}

Prior to the Coupled Model Intercomparison Project Phase 5 (CMIP5: Taylor et al., 2012), only Met Office Hadley Centre coupled climate-carbon cycle models included a dynamic vegetation model, and all other assessments of future changes in vegetation were made using offline DGVMs. The coupled climate-carbon cycle model HadCM3C (Murphy et al., 2009; Booth and Jones, 2011; Booth et al., 2012) includes a dynamic vegetation model and the carbon cycle as fully interactive components of the climate system. Vegetation interacts with the climate both through the carbon cycle and effects on the surface energy budget such as surface albedo. As part of the European Union Project, "CARBO-North - Quantifying the carbon budget in Northern Russia: past, present and future" (Kuhry, 2010), the aim of our study was to use HadCM3C to quantify the climate impact of ecosystem changes in northern Eurasia over recent decades and under future scenarios, due to changes in both biogeochemical and biogeophysical effects. We use two future scenarios the Intergovernmental Panel on Climate Change (IPCC) Special Report on Emissions Scenarios (SRES) A1B scenario (Nakićenović et al., 2000), and a climate stabilisation scenario (2C20; May, 2008), allowing us to assess the impact of climate mitigation on results. We performed a pair of simulations under each scenario - one in which vegetation was fixed at the initial state (1860 and 2020, respectively) and one in which vegetation changes dynamically in response to climate change, as determined by the interactive vegetation model within HadCM3C. However, since our simulations were global (and vegetation changes occurred over the 
whole globe, not just over the CARBO-North study region in northeastern Russia), we describe global results from our simulations, and investigate impacts over regions where significant changes in vegetation cover occurred (the Amazon and high latitude regions). Significant changes in ecosystem distribution and resulting impacts on climate over these two regions have also been illustrated in previous studies (see Sects. 1.1 and 1.2). Kuhry (2010) describes simulations with the ECHAM5/MPI-OM climate model, using data for vegetation changes from our A1B simulations where only highlatitude vegetation changes were implemented (see Sect. 4).

The aim of our study was to investigate the following key questions:

1. How do differences in vegetation changes under the two future scenarios differ?

2. How do general aspects of climate change differ between the two scenarios (A1B and $2 \mathrm{C} 20$ ) in the simulations with interactive vegetation?

3. How does the impact of vegetation change on key surface climate variables in our simulations affect mitigation advice?

There are several key differences between our study and recent related work. Many previous studies have investigated the impacts of human-induced land cover change on climate, or of prescribed changes in land cover (e.g. Lean and Warrilow, 1989; Pielke et al., 1998; Feddema et al., 2001; Betts, 2001, 2005; Falloon and Betts, 2006; Betts et al., 2007; Pitman et al., 2009; Swann et al., 2010; Lawrence and Swenson, 2011), although most of these did not include interactions with future climate change, or use dynamic vegetation models.

Global assessments of vegetation impacts on climate have either studied only 20th century climate-vegetation feedbacks (Strengers et al., 2010) or assessed future feedbacks using an equilibrium (not dynamic) vegetation model and not including biogeochemical responses (Jiang et al., 2011). Regional studies using interactive vegetation models have also been performed for Europe (Wramneby et al., 2010) under one emissions scenario and the high latitudes (but not including interactions with future climate change; Swann et al., 2010). Our study uses a fully coupled atmosphere ocean GCM with an interactive carbon cycle, whereas the study of Swann et al. (2010) used slab (mixed-layer thermodynamics only) and fixed (sea surface temperature) ocean models. Our simulations are also fully dynamic integrations with two future scenarios, in contrast to the time-slice simulations employed by Swann et al. (2010).

Our study does not consider the influence of anthropogenic land use change. However, recent simulations performed with the second version of the Met Office Hadley Centre Global Environmental Model (Earth System-HadGEM2-ES) for the fifth IPCC assessment report do include both anthro- pogenic land use change and interactive (natural) vegetation changes (Collins et al., 2011; Jones et al., 2011).

\section{Methods}

\subsection{HadCM3C coupled climate-carbon cycle model}

The model used as the basis of this study is a configuration of Version 3 of the Hadley Centre GCM, HadCM3C (Murphy et al., 2009; Booth and Jones, 2011; Booth et al., 2012), which is a version of the Met Office Unified Model (MetUM). This is a flux adjusted version (using an updated algorithm to that described by Collins et al., 2006) of HadCM3 (Gordon et al., 2000) coupled to the land surface and terrestrial carbon cycle component with interactive vegetation (TRIFFID: Cox et al., 1999, 2000; Cox, 2001) and an ocean carbon cycle (HadOCC: Palmer and Totterdell, 2001). In coupled GCMs with a fully dynamic ocean component such as HadCM3, flux adjustment involves iterative adjustments to the ocean surface heat and water fluxes which themselves are first calibrated from a preliminary integration relaxed to observed climatological fields, and then applied to subsequent control and climate change simulations (Collins et al., 2006). The need for flux adjustments arises from errors in ocean transport and ocean-atmosphere exchanges. HadCM3C differs from HadCM3LC (Cox et al., 2000; Jones et al., 2003, 2005), and the coupled climate-carbon cycle model submitted to the Coupled Climate Carbon Cycle Model intercomparison (C4MIP), as it is configured to run with the standard (higher) $\mathrm{HadCM} 3$ resolution ocean $\left(1.25^{\circ} \times 1.25^{\circ}\right)$ and also contains modelled interactive atmospheric sulphur cycle chemistry and a sulphate aerosol scheme including the direct and first indirect "cloud albedo" and aerosol effects (following Jones et al., 2001; note that the second indirect "cloud lifetime" effect is excluded). HadCM3C was recently used in the United Kingdom Climate Projections Project (UKCP - Murphy et al., 2009) and in the European Union project ENSEMBLES (Van der Linden and Mitchell, 2009).

\subsection{MOSES2 land surface scheme and TRIFFID dynamic vegetation model}

HadCM3C includes the Met Office Surface Exchange Scheme Version 2 (MOSES2 - Essery et al., 2001, 2003; Smith et al., 2006). MOSES2 (fully described by Essery et al., 2003) employs a tiled model of sub-grid heterogeneity, and includes seasonally varying vegetation (Martin et al., 2006). Separate surface temperatures, shortwave and longwave radiative fluxes, sensible and latent heat fluxes, ground heat fluxes, canopy moisture contents, snow masses and snow melt rates are computed for each surface type in a grid box. These are then aggregated to form a grid-square mean with weightings equal to the fractions of each type in the grid square. Air temperature, humidity and wind speed on atmospheric model levels above the surface and soil temperatures 
and moisture contents below the surface are treated as homogeneous across a grid box.

Nine surface types are recognized in MOSES2 (as applied in HadCM3C): broadleaf trees, needleleaf trees, C3 (temperate) grass, C4 (tropical) grass, shrubs, urban, inland water, bare soil and ice. Except for those classified as land-ice, a land grid box can be made up from any mixture of the first eight surface types. Fractions of surface types within each land-surface grid box are read from an ancillary file (as in our FIXVEG experiments) or modelled by the dynamic vegetation model TRIFFID (Cox, 2001), as in our INTVEG experiments. Each type of vegetation is associated with a canopy height, a snow-free roughness length and a canopy water capacity which are parameterized functions of the leaf area index (LAI), following Essery et al. (2001). Each vegetated tile also has an exponential root density distribution depending on the plant type. There are four soil layers in MOSES, each with a temperature and moisture content, and four soil layers have thicknesses from the surface downwards of $0.1,0.25$, 0.65 and 2.0 metres.

When the interactive vegetation scheme is included, TRIFFID models the state of the biosphere in terms of the soil carbon, and the structure and coverage of five functional types of plant (PFTs) within each model gridbox (broadleaf tree, needleleaf tree, C3 grass, C4 grass and shrub). Carbon fluxes for each vegetation type are calculated every $30 \mathrm{~min}$ as a function of climate and atmospheric $\mathrm{CO}_{2}$ concentration, from a coupled photosynthesis/stomatal-conductance scheme (Cox et al., 1998, 1999), which utilizes existing models of leaf-level photosynthesis in C3 and C4 plants (Collatz et al., 1991, 1992). The accumulated fluxes are used to update the vegetation and soil carbon every 10 days. The natural land cover evolves dynamically based on competition between the vegetation types, which is modelled using a Lotka-Volterra approach and a tree-shrub-grass dominance hierarchy. Some agricultural regions are also prescribed, in which grasslands are assumed to be dominant. Carbon lost from the vegetation as a result of local litterfall or large-scale disturbance is transferred into a soil carbon pool, where it is broken down by microorganisms that return $\mathrm{CO}_{2}$ to the atmosphere. The soil respiration rate is assumed to double for every $10 \mathrm{~K}$ of warming (Raich and Schlesinger, 1992), and is also dependent on the soil moisture content (McGuire et al., 1992). Soil $\mathrm{C}$ is modelled within TRIFFID using a single pool with a single decay rate and takes no account of input quality. Hence it cannot simulate the dynamics of different classes of soil C. Changes in the biophysical properties of the land surface (Betts et al., 1997), as well as changes in terrestrial carbon (when the interactive carbon cycle is enabled), feed back into the atmosphere. As fully described by Cox et al. (1998), plant moisture stress is determined by multiplying the potential (nonstressed) leaf photosynthesis by a soil water factor, which is itself related to the mean soil moisture concentration in the root zone, and the critical and wilting point concentra- tions, defined as the moisture levels at which photosynthesis first falls below the potential rate and is zero respectively.

\subsection{Emissions scenarios and simulations}

Table 1 summarizes our simulations, which were based on a run which was spun-up to a perpetual 1860 control state prior to the experiment. This was followed by simulations with forcings that simulate historical conditions and then two future scenarios corresponding to (a) the IPCC SRES A1B scenario (Nakićenović et al., 2000) and (b) the "2C20" stabilisation scenario specified by May (2008). These scenarios were also used in global and regional climate modelling studies performed under the EU CARBO-North project (Kuhry, 2010). The A1B simulations were all forced by $\mathrm{CO}_{2}$ emissions, natural and anthropogenic sulphur emissions, prescribed changes in minor greenhouse gas concentrations (Nakićenović et al., 2000), ozone concentrations (Meehl et al., 2007), solar forcing and also background and large-scale volcanic eruptions for the historical period (Fig. 1 - as used by Stott et al., 2006). For comparison, the setup of the A1B simulation using the "standard" version of HadCM3 (without an interactive carbon cycle) is also summarized in Table 1, and forcings for that simulation are shown in Fig. 1.

May (2008) defined the original 2C20 stabilisation scenario, which is broadly based on the "EU target" to limit global average temperature increases to below $2 \mathrm{~K}$ over preindustrial levels, and to keep global atmospheric $\mathrm{CO}_{2}$ concentrations below 550 ppmv. Using the ECHAM5/MPIOM model, May (2008) applied observed concentrations of well-mixed greenhouse gases (GHGs) including $\mathrm{CO}_{2}$ from 1861-2000, then following the A1B scenario from 20012020, and using constant concentrations from 2020 onwards. Ozone and sulphate concentrations used observed values from 1861-2000, A1B values from 2001-2020. From 20212036 the levels of A1B for 2100 were reached (i.e. five times faster than A1B), and from 2037-2100 constant 2100 A1B concentrations were applied. The global average temperature change relative to 1861-1990 values, projected by the ECHAM5/MPI-OM model for 2071-2100, was $1.92 \mathrm{~K}$ under the $2 \mathrm{C} 20$ scenario, compared to $3.47 \mathrm{~K}$ for the A1B scenario (May, 2008). Figure 1 also shows the $\mathrm{CO}_{2}$ and sulphate concentrations, and total forcings used in the Representative Concentration Pathways (RCPs) applied in the IPCC's forthcoming fifth assessment report (Van Vuuren et al., 2011) this allows comparison with the latest climate scenarios.

The forcings applied in our simulations under the A1B and 2C20 simulations are shown in Fig. 1. Many aspects of the HadCM3C and ECHAM5/MPI-OM A1B and 2C20 simulations were very similar or identical (e.g. 2020 atmospheric concentrations of $\mathrm{CH}_{4}=2026 \mathrm{ppbv}, \mathrm{N}_{2} \mathrm{O}=331 \mathrm{ppbv}$, CFC-12=486 pptv). However, due to the difference in climate model structure and setup, some aspects of our A1B and 2C20 simulations varied from those of May (2008). The resolutions of the atmosphere and ocean models differ 
Table 1. Climate simulations.

\begin{tabular}{|c|c|c|c|c|c|c|}
\hline & $\begin{array}{l}\text { Time } \\
\text { period }\end{array}$ & & $\begin{array}{l}\mathrm{CO}_{2} \\
\text { concentrations }\end{array}$ & $\begin{array}{l}\text { Other } \\
\text { GHGs }\end{array}$ & $\begin{array}{l}\text { Carbon } \\
\text { cycle }\end{array}$ & $\begin{array}{l}\text { Vegetation } \\
\text { distribution }\end{array}$ \\
\hline A1B & $1859-2100$ & (prescribed) & $\begin{array}{l}\text { Prescribed according to } \\
\text { Nakićenović et al. (2000) }\end{array}$ & A1B & Off & Fixed \\
\hline \multirow[t]{2}{*}{$\begin{array}{l}\text { A1B } \\
\text { (C cycle })\end{array}$} & $1859-2100$ & INTVEG & $\begin{array}{l}\text { From model carbon cycle } \\
\text { using A1B emissions }\end{array}$ & A1B & Fully interactive & $\begin{array}{l}\text { TRIFFID Dynamic } \\
\text { vegetation model }\end{array}$ \\
\hline & & FIXVEG & From A1B-INTVEG & $\mathrm{A} 1 \mathrm{~B}$ & Off & From 1860 A1B-INTVEG \\
\hline \multirow[t]{2}{*}{$2 \mathrm{C} 20$} & $2020-2100$ & INTVEG & 2020 A1B-INTVEG & $2 \mathrm{C} 20$ & $\begin{array}{l}\text { Uncoupled land } \\
\text { carbon cycle }\end{array}$ & $\begin{array}{l}\text { TRIFFID Dynamic } \\
\text { vegetation model }\end{array}$ \\
\hline & & FIXVEG & 2020 A1B-INTVEG & $2 \mathrm{C} 20$ & Off & From 2020 A1B-INTVEG \\
\hline
\end{tabular}
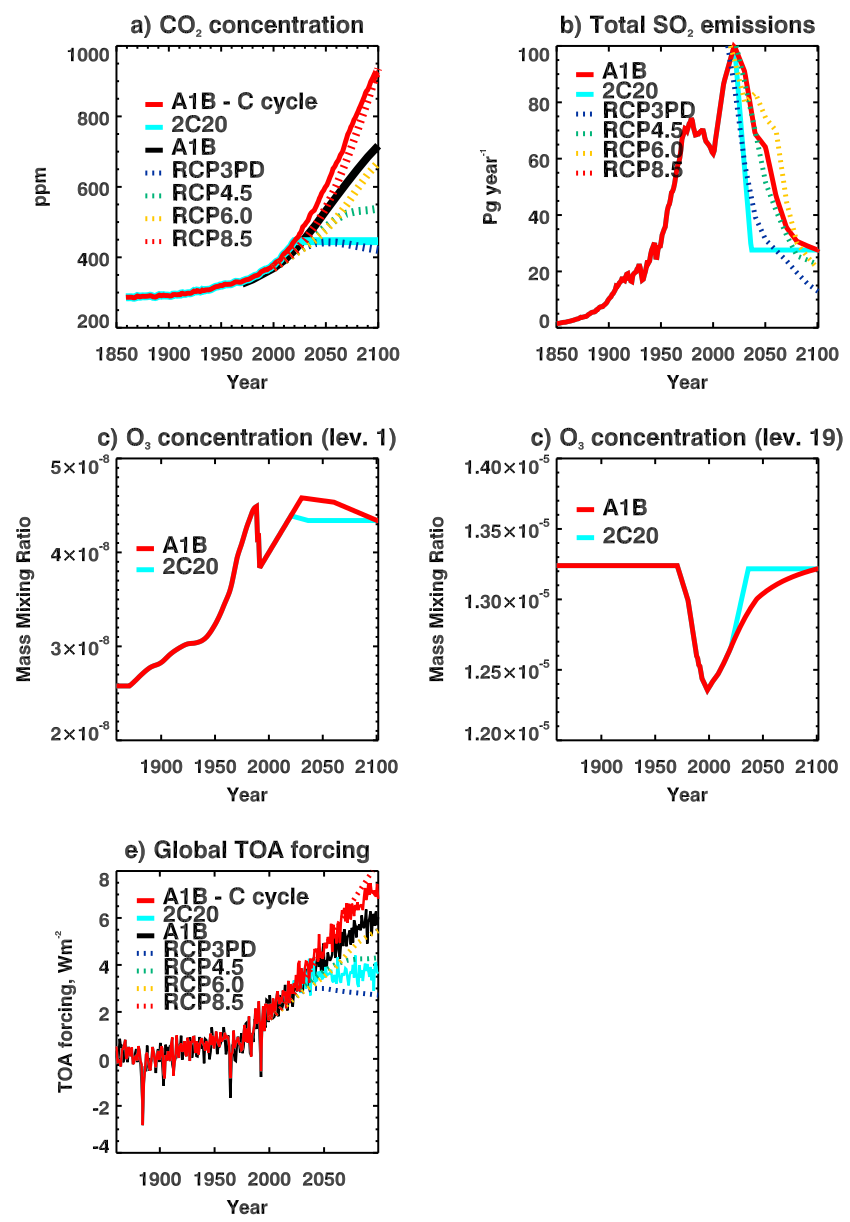

Fig. 1. Global average time series of forcings applied in the HadCM3C climate model simulations for the A1B and 2C20 scenarios: (a) $\mathrm{CO}_{2}$ concentration; (b) total $\mathrm{SO}_{2}$ emissions; (c) ozone concentration (lowest atmospheric level); (d) ozone concentration (top atmospheric level); (e) top of the atmosphere radiative forcing. Values for the Representative Concentration Pathways (RCPs) applied in the IPCC's fifth assessment report are also shown (a, b and e). The A1B-C cycle simulation corresponds to our INTVEG and FIXVEG simulations; A1B alone is the standard "prescribed" concentration scenario.
(HadCM3C: $2.5^{\circ} \times 3.75^{\circ}$ atmosphere, $1.25^{\circ} \times 1.25^{\circ}$ ocean; ECHAM5/MPI-OM: $1.9^{\circ} \times 1.9^{\circ}$ atmosphere, $1.5^{\circ} \times 1.5^{\circ}$ ocean). HadCM3C additionally includes a fully interactive carbon cycle (and hence uses $\mathrm{CO}_{2}$ emissions, rather than concentrations), whereas ECHAM5/MPI-OM does not. This, in combination with the carbon cycle-climate feedback in HadCM3C, resulted in greater $\mathrm{CO}_{2}$ concentrations in 2020 (440 ppmv vs. 418 ppmv for HadCMC3 and ECHAM5/MPIOM, respectively - see Fig. 1a). Other differences between the model setups are described by Falloon et al. (2012).

Since the aim of our study simulations was to assess the role of vegetation change under future climate conditions, we performed two simulations for each future scenario. In one simulation, the vegetation cover in the model was allowed to evolve dynamically as determined by the TRIFFID interactive vegetation model (INTVEG) - A1B-INTVEG and 2C20-INTVEG for the A1B and 2C20 scenarios, respectively. In the other set of simulations, vegetation was fixed at the initial state from the corresponding period in the A1BINTVEG simulation - in the year 1860 for the A1B simulation (A1B-FIXVEG), and in 2020 for the $2 \mathrm{C} 20$ simulation (2C20-FIXVEG). A1B-FIXVEG used annual $\mathrm{CO}_{2}$ concentrations for the atmosphere and ocean from A1B-INTVEG throughout, while 2C20-FIXVEG used the 2020 values from A1B-INTVEG. Note that because they were driven by $\mathrm{CO}_{2}$ concentrations (not emissions), the carbon cycle in both the 2C20-INTVEG and FIXVEG simulations and the A1BFIXVEG run were not coupled to the climate. Effectively this meant that only the A1B-INTVEG considered the impact of changing carbon stocks on the climate; in $2 \mathrm{C} 20$ the terrestrial carbon stores changed in response to climate, but did not affect the climate. Note also that, in the INTVEG simulations, only the PFT surface fractions (broadleaf trees, needleleaf trees, $\mathrm{C} 3$ grass, $\mathrm{C} 4$ grass and shrubs) plus bare soil change; the remaining surface fractions remain constant (urban, inland water, and ice). In addition, no anthropogenic land use change is applied in these simulations. 


\subsection{Evaluation of simulated present-day climate and vegetation}

Validation of the HadCM3 model (without a carbon cycle) is described in detail by Johns et al. (2003) and Collins et al. (2001). Some generic errors include annual precipitation underestimates over Amazonia, and precipitation overestimates over central Africa, and in general HadCM3 appears to have an overly strong hydrological cycle (Pardaens et al., 2003). HadCM3 generally captures the patterns of seasonal mean precipitation well for December-February and June-August, with generally better agreement between model and observations over land (Johns et al., 2006). In both December-February and June-August, HadCM3 tends to overestimate precipitation in the eastern tropical Atlantic/Gulf of Guinea, but the model underestimates precipitation in June-August over tropical South America (Johns et al., 2006). In general, the performance of HadCM3C (including a carbon cycle) is similar, although inclusion of the dynamic vegetation model appears to negatively influence simulation of the Indian Monsoon (McCarthy et al., 2012).

Figures S1-S4 compare the simulated annual and seasonal temperature and precipitation patterns from the HadCM3C INTVEG simulation described below, for the 1971-2000 period with observational estimates from the CRU temperature dataset (New et al., 1999) and the GPCPv2 precipitation dataset (Adler et al., 2003). While HadCM3 reproduces general patterns in temperature and precipitation well, in the annual mean the model shows warm biases over the Amazon and Canada, and cold biases over the far north of Europe and the Himalayas (Fig. S1). The model overestimates annual precipitation over central Africa, parts of South America and China, but is too dry over the Amazon and India (Fig. S2). Seasonal biases generally follow similar patterns to the annual mean biases, although HadCM3C additionally shows warm biases in June-August over much of North America and Eurasia (Fig. S3).

We also used the SAGE database (Ramankutty and Foley, 1999) to compare simulated vegetation distribution with estimates of observed coverage. SAGE represents an estimate of the present-day coverage of natural vegetation, in the absence of human land use influences, thus providing a useful dataset to compare with the HadCM3C simulation, which does not include land use change. To facilitate comparison between simulated PFT coverage and the SAGE database, SAGE vegetation classes were first converted to MOSES PFTs following the approach of Pacifico et al. (2011). Since this conversion process introduces some uncertainties, results are presented as aggregated vegetation types (tree, grass, shrub and bare soil), rather than the individual PFTs.

Figure S6 compares simulated vegetation fractions averaged over 1971-2000 with the SAGE dataset. In general, simulated vegetation patterns are reasonable. However, HadCM3C tends to overestimate the intensity of tropical forest coverage (as also shown by Booth and Jones, 2011) and underestimate boreal forest coverage, particularly over Siberia. The latter issue is likely to be because TRIFFID does not include a cold deciduous needleleaf tree (such as larch), which is an important vegetation type in eastern Siberia (Collins et al., 2011). The area that would normally be occupied by cold deciduous needleleaf trees is instead replaced in TRIFFID by an overestimation of shrubs. Finally, the model tends to underestimate bare soil coverage, particularly for low fractional coverage in mid- to high latitudes. Vegetation fractions changed very little in the long control run (Table 2).

\subsection{Analysis approach}

With the exception of time series, changes in climate variables were analysed using 30-yr means for the time periods in question. Our study focuses on annual and seasonal timescales. Seasonal averages are calculated for the following periods: December to February (DJF), March to May (MAM), June to August (JJA) and September to November (SON). Additional figures for seasonal average changes under the $2 \mathrm{C} 20$ scenario and for other variables are shown in the Supplement. Changes were assessed as global area averages, and for two regions where marked changes in terrestrial ecosystems occurred in our simulations (Fig. S5) - the Amazon region (AMZ: $40-70^{\circ} \mathrm{W}, 15^{\circ} \mathrm{S}-5^{\circ} \mathrm{N}$ ) and the northern high latitude region (HIGHLAT: $45-80^{\circ} \mathrm{N}$ ). These regions were also studied by Jones et al. (2010). In the present study, changes are calculated over these regions both for the whole region (including ocean grid points) and for land grid points only. Changes in climate variables $(\Delta V)$ under the A1B and $2 \mathrm{C} 20$ scenarios are assessed as the difference between the 2080s (2071-2100) period for each future scenario $\left(V_{\text {future }}\right)$, and the 1870 s (1861-1890) period ( $V_{\text {historic }}$ ) from the historic simulation, as follows:

$\Delta V=V_{\text {future }}-V_{\text {historic }}$.

By separately calculating the change in climate variables for the INTVEG $\left(\Delta V_{\text {INTVEG }}\right)$ and FIXVEG $\left(\Delta V_{\text {FIXVEG }}\right)$ simulations, the influence of vegetation change $\left(\Delta C_{\mathrm{VEG}}\right)$ is then assessed as

$\Delta V_{\mathrm{VEG}}=\Delta V_{\mathrm{INTVEG}}-\Delta V_{\mathrm{FIXVEG}}$.

We also used data from a 240-yr control simulation of HadCM3C with pre-industrial forcings to assess changes in climate variables (in the maps shown in the Supplement) in our A1B and 2C20 simulations relative to "natural variability" in the control simulation. In the present study, we define natural variability as \pm two standard deviations of the control simulation (Collins et al., 2001; Cowling et al., 2009). Excluding changes within \pm two standard deviations of the control simulation is approximately equivalent to a signalto-noise ratio of 2 (Hawkins and Sutton, 2011). Note that the global and regional average changes shown in the tables (and main figures) are presented as means across the full datasets 
- changes due to natural variability are not excluded as described above.

In order to take account of variations in insolation, surface albedo values $(\alpha)$ were calculated from total downward ( $\left.R \downarrow_{\text {tot }}\right)$ and net downward shortwave radiation fluxes ( $\left.R \downarrow_{\text {net }}\right)$ at the surface as follows:

$\alpha=\frac{R \downarrow_{\text {tot }}-R \downarrow_{\text {net }}}{R \downarrow_{\text {tot }}}$.

Clear-sky albedo values $\left(\alpha_{\mathrm{c}}\right)$ were calculated from the ratio of the clear-sky upward shortwave radiation flux at the surface $\left(R \uparrow_{\mathrm{c}}\right)$ to the clear-sky downward shortwave radiation flux at the surface $\left(R \downarrow_{\mathrm{c}}\right)$ :

$\alpha_{\mathrm{c}}=\frac{R \uparrow_{\mathrm{c}}}{R \downarrow_{\mathrm{c}}}$.

\section{Results}

\subsection{Vegetation changes}

Between 1961-1990 and 2071-2100 under A1B, there was a gain in the global area under needleleaf trees, shrub and bare soil and a loss of broadleaf trees, C3 grasses and C4 grasses (Figs. 2 and S7; Table 2). Globally, the increase in shrub and needleleaf coverage was most rapid between 2000 and 2100 under A1B, while the rate of change slowed after around 2020-2030 under the 2C20 scenario. Broadleaf tree and $\mathrm{C} 4$ grass coverage both increased globally until 2050 and 2000, respectively, and declined thereafter, with less marked changes under 2C20. The global gains in shrub and needleleaf tree area were mostly accounted for by changes in the high latitude regions, while the global losses of broadleaf tree, C3 and C4 grasses were mostly driven by the changes over the Amazon region.

Changes in PFT composition were much more marked over our two focus regions. During the same time period over the Amazon under A1B, the area under broadleaf trees was strongly reduced, and C3 grass, $\mathrm{C} 4$ grass and shrub coverage also contracted. These vegetation types were largely replaced by bare soil, which expanded considerably. Over the Amazon, losses of C3 grass coverage occurred in the east, while gains were found in western parts.

In contrast, over the HIGHLAT region under A1B, the area of bare soil contracted, along with $\mathrm{C} 3$ and $\mathrm{C} 4$ grass, being replaced by an expansion of broadleaf and needleleaf trees, and shrub. At high latitudes, increases in shrub cover and losses of C3 grass were most marked over Siberia, while some losses of shrub cover occurred over northeastern Russia and Alaska.

\subsection{Terrestrial carbon storage}

Averaged over 1861-1890, the global total carbon stocks in our simulations were 1144,514 and $1658 \mathrm{Pg} \mathrm{C}$ for soil,
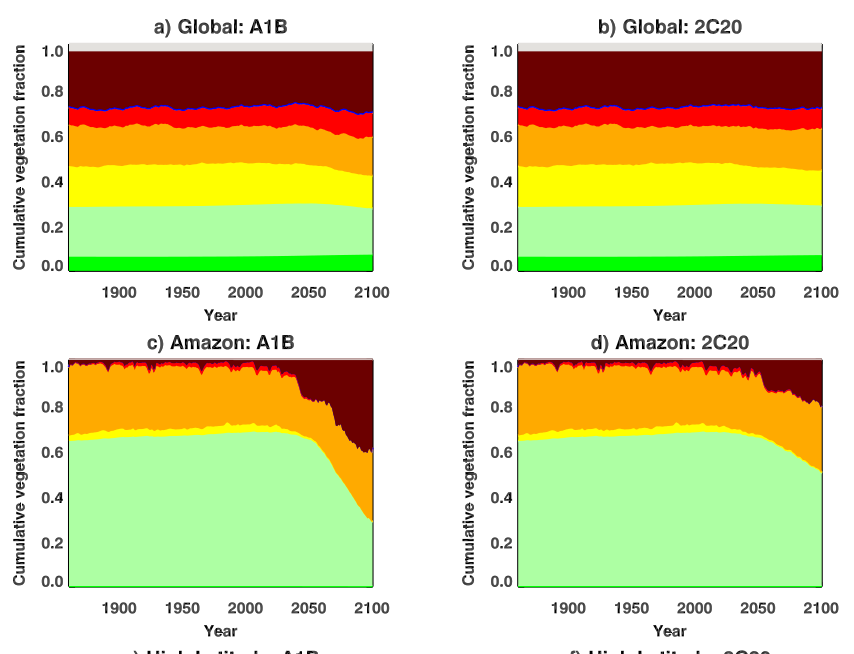

e) High Latitude: A1B
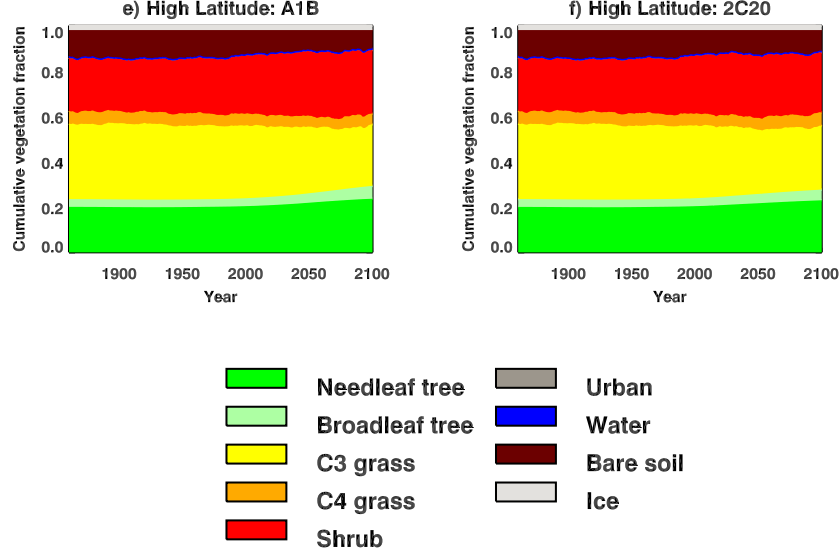

Fig. 2. Time series of relative contribution of surface types in HadCM3C simulations under the A1B and 2C20 scenarios with interactive vegetation: (a) global mean, (b) Amazon region, and (c) high latitude region. Regions are defined in Table 2.

vegetation and total land carbon, respectively. As noted in Sect. 2.3, our simulations (and hence these initial values) were based on a run which was spun-up to a perpetual 1860 control state prior to the experiment. Global total mean carbon stocks increased during the 20th century until around 2020 under both INTVEG simulations and declined strongly thereafter under A1B (Table 3, Figs. 3 and S8) with a slower rate of decline under $2 \mathrm{C} 20$.

Strong reductions in total carbon storage were found over AMZ (Figs. 3, S8, and S9) under A1B as a result of both soil and vegetation carbon changes, although vegetation carbon changes appear to dominate. Under 2C20, much smaller total carbon reductions were found over AMZ, with changes in vegetation carbon also dominating. Over HIGHLAT, increases in total carbon storage were found under both A1B and $2 \mathrm{C} 20$. The differences in total carbon changes between A1B and 2C20 were mostly driven by soil carbon changes over HIGHLAT. 
Table 2. Simulated vegetation fractions in the A1B-INTVEG simulations (\% coverage)

\begin{tabular}{|c|c|c|c|c|c|c|c|}
\hline \multirow{2}{*}{$\begin{array}{l}\text { Plant } \\
\text { functional } \\
\text { type }\end{array}$} & \multirow{2}{*}{$\begin{array}{l}\text { Global standard } \\
\text { deviation in } \\
\text { long control run }\end{array}$} & \multicolumn{3}{|c|}{$1870 \mathrm{~s}^{\mathrm{a}}$} & \multicolumn{3}{|c|}{$2080 s^{b}$} \\
\hline & & Global & $\begin{array}{r}\text { High } \\
\text { latitude }^{c}\end{array}$ & Amazon $^{\mathrm{d}}$ & Global & $\begin{array}{r}\text { High } \\
\text { latitude }^{c}\end{array}$ & Amazon $^{\mathrm{d}}$ \\
\hline Broadleaf tree & 0.13 & 22 & 3 & 64 & 21 & 5 & 39 \\
\hline Needleleaf tree & 0.02 & 6 & 20 & - & 7 & 23 & - \\
\hline C3 grass & 0.16 & 18 & 33 & 3 & 15 & 26 & 0.1 \\
\hline $\mathrm{C} 4$ grass & 0.42 & 18 & 6 & 30 & 16 & 5 & 25 \\
\hline Shrub & 0.06 & 7 & 23 & 0.5 & 10 & 28 & 0.03 \\
\hline Bare soil & 0.38 & 25 & 12 & 2 & 26 & 9 & 36 \\
\hline
\end{tabular}

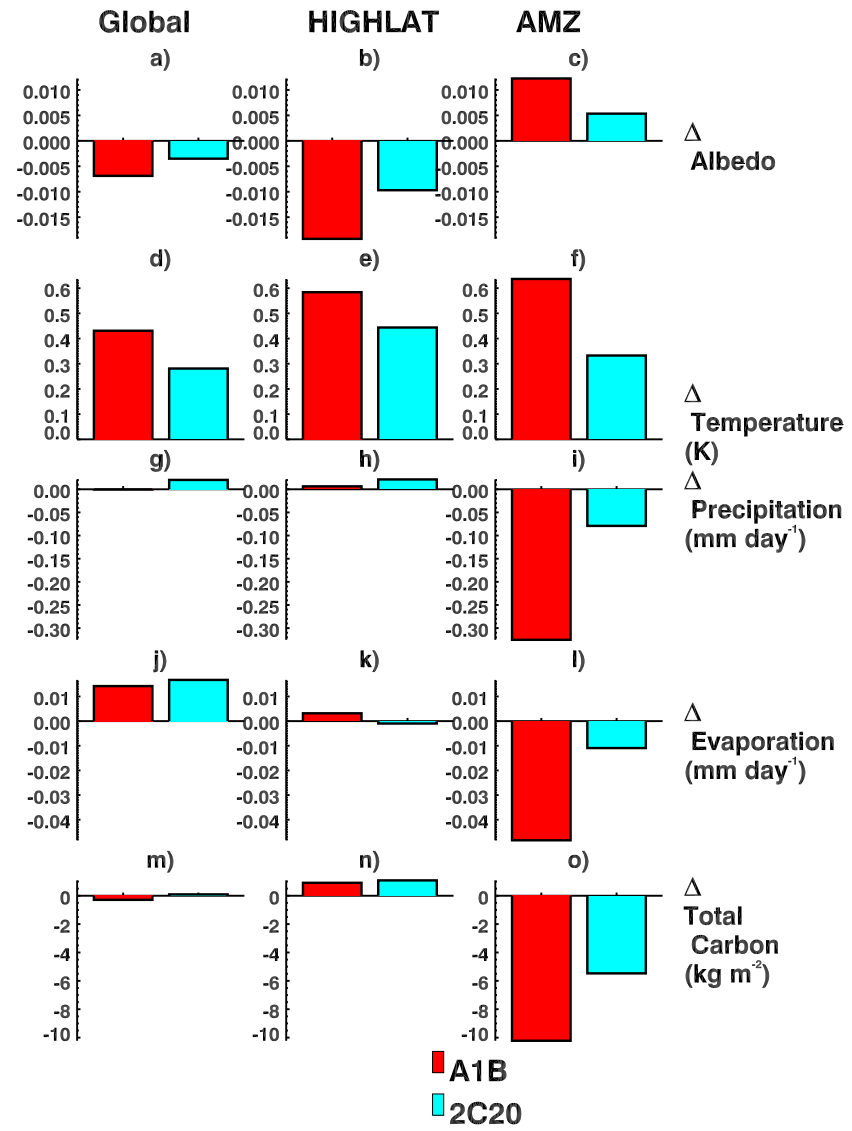

Fig. 3. Changes in selected annual mean climate and ecosystem variables (over land points only) as a result of interactive vegetation (INTVEG-FIXVEG) for the 2080s-1860s under the A1B and 2C20 scenarios, for global mean (a, d, $\mathbf{g}, \mathbf{j}, \mathbf{m})$, Amazon region (b, $\mathbf{e}, \mathbf{h}, \mathbf{k}, \mathbf{n})$, and high latitude region $(\mathbf{c}, \mathbf{f}, \mathbf{i}, \mathbf{l}, \mathbf{o})$. Regions are defined in Table 2.

\subsection{Surface albedo}

Interactive vegetation changes reduced albedo globally and over HIGHLAT under both A1B and 2C20, while over AMZ albedo increased under A1B with smaller increases under 2C20 (Table 3, Figs. 3 and S10). Changes in surface albedo due to vegetation change were generally more marked seasonally, compared to the annual average changes (Figs. 4, S11 and S12), although seasonal differences were similar during all seasons over the Amazon. In particular, strong reductions in albedo were seen across mid-high latitudes in DJF and high latitudes in MAM; in contrast to the annual mean decrease, small increases in albedo were found during JJA across Siberia. Seasonal changes in temperature under 2C20 (Figs. 4 and S11) were largely a diminished pattern of those found under A1B. The main exception was stronger albedo reduction under 2C20 during DJF for the far west of Europe and northeastern Russia, covering a region between approximately 45 to $65^{\circ} \mathrm{N}$ and 25 to $75^{\circ} \mathrm{E}$. The reduction in albedo during DJF was smaller under A1B for this region, with some increases in albedo in the eastern parts. Changes in clear-sky albedo (Fig. S13, Table 3) were almost identical to those in surface albedo, indicating that vegetation changes did not have major impacts on cloudiness in our simulations.

\subsection{Near surface temperature}

Global mean temperature increases between 1861-1990 and 2071-2100 (Table 3, Fig. S14) under both the A1B and $2 \mathrm{C} 20$ simulations using HadCM3C with interactive vegetation were greater than the values found by May (2008) using ECHAM5/MPI-OM (3.47 and $1.92 \mathrm{~K}$ respectively). Global mean temperature increases under our simulations with fixed vegetation were smaller than those with interactive vegetation, but still greater than those found by May (2008). Under the A1B scenario, much larger changes in annual mean temperature were found under our simulations for AMZ and HIGHLAT (Figs. 3 and S15). 
Table 3. Changes in selected climate and ecosystem variables

\begin{tabular}{|c|c|c|c|c|c|c|c|}
\hline \multirow[t]{2}{*}{$\begin{array}{l}\text { Change in ecosystem/ } \\
\text { climate variable }\end{array}$} & & \multicolumn{2}{|c|}{$\begin{array}{c}\text { A1B } \\
\left(2080 s^{a}-1870 s^{b}\right)\end{array}$} & \multicolumn{2}{|c|}{$\begin{array}{c}2 \mathrm{C} 20 \\
(2080 \mathrm{~s}-1870 \mathrm{~s})\end{array}$} & \multicolumn{2}{|c|}{$\begin{array}{c}\text { Impact of interactive } \\
\text { vegetation }^{c}\end{array}$} \\
\hline & & INTVEG & FIXVEG & INTVEG & FIXVEG & A1B & $2 \mathrm{C} 20$ \\
\hline \multirow{3}{*}{$\begin{array}{l}\text { Soil carbon stocks }(\mathrm{Pg} \mathrm{C}) / \\
\text { concentration }\left(\mathrm{kg} \mathrm{C} \mathrm{m}^{-2}\right)\end{array}$} & Global & $-109 /-0.74$ & - & $-40 /-0.27$ & - & - & - \\
\hline & High latitude $^{\mathrm{d}}$ & $-23 /-0.56$ & - & $4 / 0.09$ & - & - & - \\
\hline & Amazon $^{\mathrm{e}}$ & $-30 /-4.32$ & - & $-16 /-2.31$ & - & - & - \\
\hline \multirow{3}{*}{$\begin{array}{l}\text { Vegetation carbon stocks }(\mathrm{Pg} \mathrm{C}) / \\
\text { concentration }\left(\mathrm{kg} \mathrm{C} \mathrm{m}^{-2}\right)\end{array}$} & Global & $67 / 0.45$ & - & $54 / 0.37$ & - & - & - \\
\hline & High latitude $\mathrm{d}^{\mathrm{d}}$ & $61 / 1.48$ & - & $41 / 0.99$ & - & - & - \\
\hline & Amazon ${ }^{\mathrm{e}}$ & $-41 /-5.90$ & - & $-22 /-3.16$ & - & - & - \\
\hline \multirow{3}{*}{$\begin{array}{l}\text { Total carbon stocks }(\mathrm{Pg} \mathrm{C}) / \\
\text { concentration }\left(\mathrm{kg} \mathrm{C} \mathrm{m}^{-2}\right)\end{array}$} & Global & $-43 /-0.29$ & - & $14 / 0.10$ & - & - & - \\
\hline & High latitude $^{\mathrm{d}}$ & $38 / 0.91$ & - & $45 / 1.08$ & - & - & - \\
\hline & Amazon $^{\mathrm{e}}$ & $-71 /-10.22$ & - & $-22 /-5.47$ & - & - & - \\
\hline \multirow{7}{*}{ Average albedo } & Global & -0.018 & -0.016 & -0.012 & -0.011 & $\begin{array}{r}-0.002 \\
(10 \%)\end{array}$ & $\begin{array}{r}-0.0006 \\
(5 \%)\end{array}$ \\
\hline & Global land & -0.017 & -0.010 & -0.012 & -0.008 & $\begin{array}{r}-0.006 \\
(40 \%)\end{array}$ & $\begin{array}{r}-0.003 \\
(30 \%)\end{array}$ \\
\hline & High latitude $\mathrm{d}^{\mathrm{d}}$ & -0.062 & -0.051 & -0.041 & -0.036 & -0.011 & -0.005 \\
\hline & High latitude & -0.047 & -0.028 & -0.032 & -0.022 & $\begin{array}{r}(18 \%) \\
-0.019\end{array}$ & $\begin{array}{r}(13 \%) \\
-0.01\end{array}$ \\
\hline & land & & & & & $(41 \%)$ & $(31 \%)$ \\
\hline & Amazon $^{\mathrm{e}}$ & 0.010 & -0.00003 & 0.002 & -0.002 & $\begin{array}{c}0.01 \\
(100 \%)\end{array}$ & $\begin{array}{r}0.004 \\
(164 \%)\end{array}$ \\
\hline & Amazon land & 0.010 & $\sim 0$ & 0.003 & -0.002 & $\begin{array}{c}0.01 \\
(100 \%)\end{array}$ & $\begin{array}{r}0.005 \\
(163 \%)\end{array}$ \\
\hline \multirow{6}{*}{ Average clear-sky albedo } & Global & -0.017 & -0.015 & -0.011 & -0.011 & $\begin{array}{r}-0.002 \\
(11 \%)\end{array}$ & $\begin{array}{r}-0.0006 \\
(5 \%)\end{array}$ \\
\hline & Global land & -0.016 & -0.009 & -0.011 & -0.008 & $\begin{array}{r}-0.007 \\
(41 \%)\end{array}$ & $\begin{array}{r}-0.003) \\
(30 \%\end{array}$ \\
\hline & High latitude ${ }^{d}$ & -0.056 & -0.046 & -0.037 & -0.032 & $\begin{array}{l}-0.01 \\
(18 \%)\end{array}$ & $\begin{array}{r}-0.005 \\
(13 \%)\end{array}$ \\
\hline & $\begin{array}{l}\text { High latitude } \\
\text { land }\end{array}$ & -0.043 & -0.025 & -0.029 & -0.02 & $\begin{array}{l}-0.02 \\
(42 \%)\end{array}$ & $\begin{array}{r}-0.009 \\
(31 \%)\end{array}$ \\
\hline & Amazon $^{\mathrm{e}}$ & 0.01 & -0.00002 & 0.003 & -0.002 & $\begin{array}{c}0.01 \\
(100 \%)\end{array}$ & $\begin{array}{r}0.004 \\
(164 \%)\end{array}$ \\
\hline & Amazon land & 0.01 & $\sim 0$ & 0.003 & -0.002 & $\begin{array}{r}0.01 \\
(100 \%)\end{array}$ & $\begin{array}{r}0.005 \\
(163 \%)\end{array}$ \\
\hline \multirow{6}{*}{ Average temperature $(\mathrm{K})$} & Global & 5.12 & 4.87 & 2.96 & 2.80 & $\begin{array}{l}0.24 \\
(5 \%)\end{array}$ & $\begin{array}{r}0.15 \\
(5 \%)\end{array}$ \\
\hline & Global land & 7.45 & 7.01 & 4.07 & 3.79 & $\begin{array}{l}0.43 \\
(6 \%)\end{array}$ & $\begin{array}{r}0.28 \\
(7 \%)\end{array}$ \\
\hline & High latitude $^{\mathrm{d}}$ & 8.33 & 7.97 & 4.77 & 4.51 & $\begin{array}{l}0.35 \\
(4 \%)\end{array}$ & $\begin{array}{r}0.26 \\
(6 \%)\end{array}$ \\
\hline & $\begin{array}{l}\text { High latitude } \\
\text { land }\end{array}$ & 8.83 & 8.24 & 4.85 & 4.40 & $\begin{array}{l}0.58 \\
(7 \%)\end{array}$ & $\begin{array}{r}0.44 \\
(9 \%)\end{array}$ \\
\hline & Amazon $^{\mathrm{e}}$ & 8.59 & 8.02 & 4.71 & 4.41 & $\begin{array}{l}0.56 \\
(7 \%)\end{array}$ & $\begin{array}{r}0.30 \\
(6 \%)\end{array}$ \\
\hline & Amazon land & 9.52 & 8.88 & 5.17 & 4.84 & $\begin{array}{c}0.64 \\
(7 \%)\end{array}$ & $\begin{array}{r}0.33 \\
(6 \%)\end{array}$ \\
\hline \multirow{6}{*}{$\begin{array}{l}\text { Average evaporation } \\
\left.\text { (total surface moisture flux, } \mathrm{mm} \mathrm{day}^{-1}\right) / \\
\text { latent heat flux }\left(\mathrm{W} \mathrm{m}^{-2}\right)\end{array}$} & Global & $0.13 / 3.78$ & $0.12 / 3.31$ & $0.13 / 3.63$ & $0.11 / 3.12$ & $\begin{array}{r}0.02 / 0.47 \\
(12 \%)\end{array}$ & $\begin{array}{r}0.02 / 0.52 \\
(14 \%)\end{array}$ \\
\hline & Global land & $-0.25 /-7.18$ & $-0.26 /-7.60$ & $-0.05 /-1.52$ & $-0.07 /-2.00$ & $\begin{array}{r}0.01 / 0.42 \\
(-6 \%)\end{array}$ & $\begin{array}{r}0.02 / 0.48 \\
(-32 \%)\end{array}$ \\
\hline & High latitude $^{\mathrm{d}}$ & $0.10 / 2.95$ & $0.10 / 2.81$ & $0.10 / 2.85$ & $0.09 / 2.66$ & $\begin{array}{r}0.004 / 0.14 \\
(4 \%)\end{array}$ & $\begin{array}{r}0.007 / 0.20 \\
(7 \%)\end{array}$ \\
\hline & High latitude land & $-0.02 /-0.78$ & $-0.03 /-0.89$ & $0.05 / 1.45$ & $0.05 / 1.48$ & $\begin{array}{r}0.003 / 0.11 \\
(-14 \%)\end{array}$ & $\begin{array}{r}-0.001 /-0.03 \\
(-2 \%)\end{array}$ \\
\hline & Amazon $^{\mathrm{e}}$ & $-1.37 /-39.60$ & $-1.35 /-39.03$ & $-0.58 /-16.92$ & $-0.59 /-16.97$ & $\begin{array}{r}-0.02 /-0.57 \\
(1 \%)\end{array}$ & $\begin{array}{r}0.001 / 0.04 \\
(-0.2 \%)\end{array}$ \\
\hline & Amazon land & $-1.68 /-48.77$ & $-1.64 /-47.37$ & $-0.76 /-21.98$ & $-0.75 /-21.66$ & $\begin{array}{r}-0.05 /-1.40 \\
(3 \%)\end{array}$ & $\begin{array}{r}-0.01 /-0.32 \\
(1 \%)\end{array}$ \\
\hline
\end{tabular}

a $2071-2100$

b $1861-1890$

c INTVEG (2080s-1870s)-FIXVEG (2080s-1870s). Figures in parentheses are relative changes, as a percentage of the change in the respective INTVEG simulation (2080s-1870s).

${ }^{d}$ HIGHLAT: $45-80^{\circ} \mathrm{N}$

e AMZ: $40-70^{\circ} \mathrm{W}, 15^{\circ} \mathrm{S}-5^{\circ} \mathrm{N}$ 


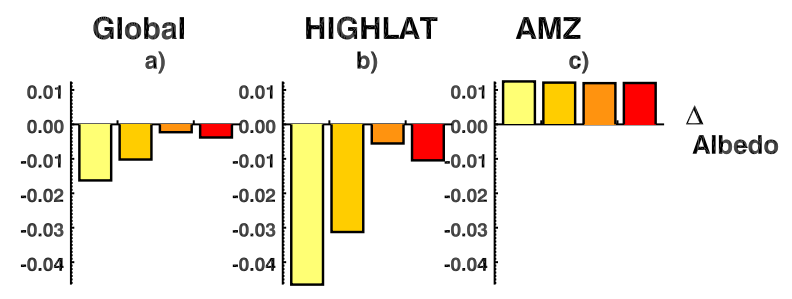

d)

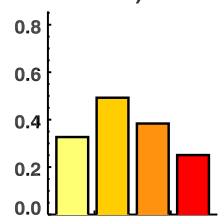

g)

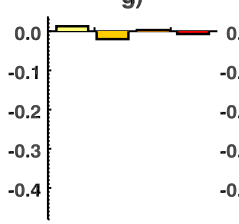

j)
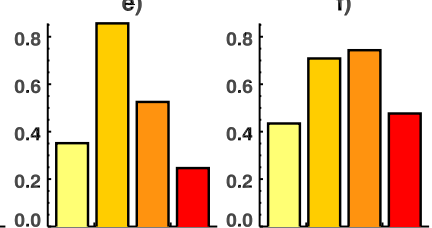

h)

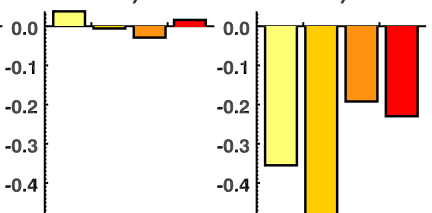

l)
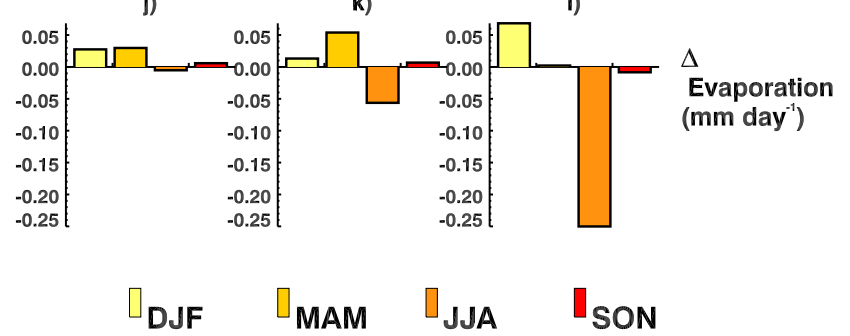

Fig. 4. Changes in selected seasonal mean climate and ecosystem variables (over land points only) as a result of interactive vegetation (INTVEG-FIXVEG) for the 2080s-1860s under the A1B scenario, for global mean (a, d, g, j), Amazon region (b, e, h, k), and high latitude region $(\mathbf{c}, \mathbf{f}, \mathbf{i}, \mathbf{l})$. Regions are defined in Table 2 .

The impact of interactive vegetation on global mean temperature changes in our simulations was relatively small, and greater under the A1B scenario than under the 2C20 scenario. Regionally, the absolute impact of interactive vegetation under the A1B simulations on temperature was greater than the global value for both AMZ and HIGHLAT, while slightly smaller regional impacts were found under the $2 \mathrm{C} 20$ scenario. In response to vegetation change, larger seasonal changes in temperature were found compared to the annual mean changes (Figs. 4 and S16). This was particularly the case during MAM, when warming exceeding $1.5 \mathrm{~K}$ was found across Siberia, parts of northeastern Russia, Alaska and northern Canada, and the eastern Amazon. Seasonal changes in temperature under 2C20 (Figs. 4 and S17) were largely a diminished pattern of those found under A1B. The main exception was stronger warming during DJF and JJA for the far west of Europe and northeastern Russia, between approximately 45 to $65^{\circ} \mathrm{N}$ and 25 to $75^{\circ} \mathrm{E}$. Little warming was found for this region under A1B, but in contrast warming of over $1.5 \mathrm{~K}$ was found under $2 \mathrm{C} 20$.

Vegetation changes for this region were largely similar between the two scenarios. The differences in temperature changes due to interactive vegetation between the $\mathrm{A} 1 \mathrm{~B}$ and $2 \mathrm{C} 20$ scenarios for this region therefore appear to be driven by other factors (see Sects. 3.3, 3.5 and 3.6). These may include the greater precipitation increase during DJF under A1B enhancing snow cover, thus increasing albedo and leading to a greater relative temperature increase. In JJA, greater reductions in precipitation and evaporation were found under $2 \mathrm{C} 20$, which may have contributed to the larger relative temperature increases compared to A1B.

\subsection{Precipitation}

Globally, interactive vegetation led to a relatively strong increase in precipitation in both the $\mathrm{A} 1 \mathrm{~B}$ and $2 \mathrm{C} 20$ simulations (Table 3, Figs. 3 and S18). In contrast, over the HIGHLAT region, interactive vegetation led to a stronger increase in precipitation in the $2 \mathrm{C} 20$ simulation for the same time period compared to almost no impact under the A1B simulation. Strong decreases in precipitation over AMZ were found in our simulations as a result of interactive vegetation in both the $\mathrm{A} 1 \mathrm{~B}$ and $2 \mathrm{C} 20$ simulations. In other words, the loss of Amazon forest cover led to a further decrease in precipitation. Much of the changes in total precipitation in our simulations were accounted for by changes in convective precipitation (not shown). Seasonal patterns of change in precipitation due to the vegetation effect were largely similar to the annual mean changes (Fig. 4). In response to vegetation change, larger seasonal changes in precipitation were found compared to the annual mean changes (Figs. 4, S19 and S20) for some regions, most notably during DJF and MAM which dominated the annual decreases found over the Amazon. For the far west of Europe and northeastern Russia (approximately 45 to $65^{\circ} \mathrm{N}$ and 25 to $75^{\circ} \mathrm{E}$ ), there was a greater DJF precipitation increase under A1B and a weaker reduction in JJA precipitation, compared to $2 \mathrm{C} 20$.

\subsection{Evaporation and latent heat flux}

The impact of interactive vegetation changes in global annual mean evaporation changes was relatively small (Table 3 ). A slight increase was found under both A1B and 2C20. A small decrease in evaporation resulted from vegetation changes for AMZ under A1B, with a small increase under 2C20 (Figs. 3 and S21). Interactive vegetation led to a small increase in evaporation over HIGHLAT under both simulations. As for precipitation, changes in seasonal patterns of evaporation due to the vegetation effect were largely similar to the annual mean changes. In response to vegetation change, larger seasonal evaporation changes were found compared to the annual mean changes (Figs. 4, S22 and S23) for some regions. For instance, the annual increases in evaporation over the 
Amazon were dominated by MAM and JJA changes while the increases over high latitudes mostly occurred during DJF and MAM. For the far west of Europe and northeastern Russia (approximately 45 to $65^{\circ} \mathrm{N}$ and 25 to $75^{\circ} \mathrm{E}$ ), there was a greater JJA evaporation increase under $2 \mathrm{C} 20$ compared to A1B.

\section{Discussion}

\subsection{Climate simulations}

May (2008) described the original 2C20 simulation, using the ECHAM5/MPI-OM model, which provided the basis for our $2 \mathrm{C} 20$ run. We therefore discuss differences in climate projections between May (2008) and our simulations, relevant to the present study. The global average warming under the A1B scenario 2071-2100 relative to 1980-1999 in our HadCM3C INTVEG simulation was $4.33 \mathrm{~K}$, greater than that from ECHAM5/MPI-OM (3.03 K; May, 2008), while the equivalent value for HadCM3 (without a carbon cycle) is $2.72 \mathrm{~K}$ (Meehl et al., 2007). Although the equilibrium climate sensitivity (Meehl et al., 2007) of the standard HadCM3 model to doubled $\mathrm{CO}_{2}$ forcing $(3.3 \mathrm{~K})$ is less than that of ECHAM5/MPI-OM (3.4 K), including the carbon cycle (and the associated increase in atmospheric $\mathrm{CO}_{2}$ concentrations for the same emissions pathway) in HadCM3C significantly increases the model response to the same $\mathrm{CO}_{2}$ concentration forcing, compared to ECHAM5/MPI-OM. This explains the greater temperature increases found in our $\mathrm{A} 1 \mathrm{~B}$ and $2 \mathrm{C} 20$ simulations compared to the results of May (2008).

Relatively strong increases in precipitation were found under our 2C20 simulation, compared to the A1B simulations, in common with the findings of May (2008). The reason for this is likely to be the sharp reduction in sulphate aerosols (Brasseur and Roekner, 2005) over the years 2021-2036 which was applied in the $2 \mathrm{C} 20$ scenario. In agreement with our findings, in his experiments with reduced GHG concentrations, May (2008) also found stronger relative increases in precipitation since changes in global mean precipitation are not a linear function of the change in global mean temperature (Meehl et al., 2007). In addition, the hydrological sensitivity is greater for aerosol forcing than for GHG forcing (Feichter et al., 2004).

\subsection{Changes in vegetation types and terrestrial carbon storage}

Key shifts in vegetation type in our simulations included increases in needleleaf and broadleaf tree cover over high latitudes, loss of broadleaf tree cover over the Amazon and replacement with $\mathrm{C} 4$ grass, and losses of $\mathrm{C} 3$ grass in high latitudes with replacement by shrubs, particularly over eastern Siberia. These changes are in broad agreement with recent studies of future ecosystem distribution, which generally suggest replacement of herbaceous vegetation with trees at high latitudes and varying degrees of loss of the Amazon forest (Scholze et al., 2006; Sitch et al., 2008), although Jiang et al. (2011) find tropical forest expansion. For comparison, Hurtt et al. (2011) estimate that between 1500 and 2005, the global fractional area of cropland increased from 2 to $10 \%$; pasture from 2 to $22 \%$; primary vegetation decreased from $94 \%$ to $34 \%$; secondary vegetation increased from 0 to $20 \%$ and urban area increased from 0 to $0.4 \%$. Our changes in natural vegetation types were much smaller - generally of the order of $1-2 \%$ of the global land area for any one PFT.

The response of DGVMs to climate change is strongly linked to GCM climatology (Sitch et al., 2008), and their simulation of present-day vegetation cover. In our HadCM3C simulations, the baseline climate over the Amazon was too warm and dry compared to observations; most GCMs also underestimate current precipitation over the region (Malhi et al., 2009). At high latitudes, HadCM3C is too warm over Alaska and Siberia but too cold over western Eurasia. The model tends to overestimate present-day tropical forest cover but underestimate boreal forest cover, especially over Siberia. In our study, as found in the HadCM3LC C4MIP simulations (Friedlingstein et al., 2006), future drying (and warming) resulted in a loss of Amazon forest cover with local biogeophysical effects of forest loss acting to further reduce rainfall (Betts et al., 2004). In contrast, the moisture balance increases in the tropics in many GCMs (e.g. Held and Soden, 2006) although there is considerable variation in future projections (Malhi et al., 2009). Despite this, Malhi et al. (2009) note that not all GCMs can be considered as equivalent, and extreme outcomes cannot be discarded as outliers. For example, while HadCM3 produced the strongest drying signal over the Amazon, the model captures many key aspects of coupling between Atlantic sea surface temperatures and Amazonian drought. Considering errors in reproducing observed rainfall regimes in the 20th century, Malhi et al. (2009) suggest that dry season water stress is likely to increase in eastern Amazonia over the 21st century, but the region tends toward a climate more appropriate to seasonal forest than to savannah. It is therefore possible that the warm, dry bias (and overestimated forest cover) over the Amazon in HadCM3C enhanced future forest loss in our study. In our simulations, warming led to expansion of shrub cover over Siberia and boreal forest cover over Alaska and western Eurasia. Similarly, the underestimation of boreal forest cover may have enhanced simulated future forest gains, particularly over western Eurasia where there was also a presentday cold bias.

A small overall increase in total terrestrial carbon storage $(14 \mathrm{Pg} \mathrm{C})$ was found in our $2 \mathrm{C} 20$ simulation, in contrast to the decrease found for A1B $(-43 \mathrm{PgC})$. This is consistent with findings from recent studies, which suggest the conversion of the present-day land carbon sink into a source during the 21st century for stronger warming (Scholze et al., 2006). Similarly, all of the HadCM 3 C ensemble members studied by Booth and Jones (2011) and Booth et al. (2012) 
find a reduction in land carbon uptake under the A1B scenario. In agreement with Booth and Jones (2011), Booth et al. (2012) and Friedlingstein et al. (2006), much of the difference in total carbon changes between our simulations was driven by changes in soil carbon (soil: -109 and $-40 \mathrm{Pg} \mathrm{C}$; vegetation: 67 and 54, for $\mathrm{A} 1 \mathrm{~B}$ and $2 \mathrm{C} 20$, respectively). The C4MIP simulations (using the A2 scenario) find a wide spread in future global carbon stock changes (Friedlingstein et al., 2006): between 1901-1931 and 2071-2100, the ranges of changes were 22 to $708,-16$ to 348 , and 38 to $475 \mathrm{Pg} \mathrm{C}$ for total, soil and vegetation carbon respectively. The range of changes between the 2090s and the present day across the HadCM3C ensemble of Booth and Jones (2011) were -647 to $210 \mathrm{Pg} \mathrm{C}$ for soil, -83 to $183 \mathrm{Pg} \mathrm{C}$ for vegetation, and -632 to $393 \mathrm{Pg} \mathrm{C}$ for total carbon. Our future total carbon changes under A1B are therefore within the range found by Booth and Jones (2011) but outside that of the C4MIP models; differences between these studies again appear to be largely explained by differing soil responses.

Regionally, total carbon storage was reduced over the Amazon and increased over high latitudes. This is in broad agreement with recent studies (Sitch et al., 2008; Qian et al., 2010; Devaraju et al., 2011) - for instance the majority of C4MIP models locate reduction of land carbon uptake in the tropics and find an increase in high latitudes (Friedlingstein et al., 2006). The HadCM3C ensemble used by Booth and Jones (2011) also found robust vegetation carbon increases in northern high latitudes, and higher altitude lower latitude regions along with smaller regions of vegetation loss in Central America, northern Brazil, the Kalahari and Crimea. Robust soil carbon losses were found in central North America, Central America, northern South America, continental Europe and southern Africa; robust soil carbon gains were only found in the extreme north and for isolated high altitude regions.

Across the C4MIP models at northern high latitudes $\left(>60^{\circ} \mathrm{N}\right)$, Qian et al. (2010) find an increase in total carbon stocks of $38 \pm 20 \mathrm{PgC}$ over 1901 levels by 2100 , of which $17 \pm 8 \mathrm{PgC}$ come from vegetation and $21 \pm 16 \mathrm{PgC}$ from soil (increases of $43 \%$ and $8 \%$ of the vegetation and soil pools, respectively). Qian et al. (2010) found that both $\mathrm{CO}_{2}$ fertilisation and warming enhanced vegetation growth, and although the intense warming over the region enhanced decomposition, soil carbon storage continued to increase in 21st century due to increased litterfall. Our values (for land $>45^{\circ} \mathrm{N}$ ) were similar for total carbon changes $(38 \mathrm{Pg} \mathrm{C})$, larger for vegetation carbon changes $(61 \mathrm{PgC})$ and of the opposite sign for soil carbon changes $(-63 \mathrm{PgC})$. The reason for the difference between our simulated changes and those of Qian et al. (2010) is likely to be mainly the difference in averaging area - Fig. S9e shows strong losses of soil carbon around $45^{\circ} \mathrm{N}$ and gains north of around $60^{\circ} \mathrm{N}$. Kuhry (2010) describes simulations using the LPJ-GUESS DGVM for a region of northeastern European Russia, under the A1B scenario. In their simulations, the region was predicted to lose carbon due to future climate change in contrast to our findings, though the exact amount was strongly dependent the rate of forest disturbance and tree-line advance. Carbon release from permafrost is also not included in the current simulations; under the RCP 8.5 scenario with the HadGEM2ES Earth system model, Burke et al. (2012) found a range of permafrost carbon release of $50-270 \mathrm{Pg} \mathrm{C}$ by 2100 . Falloon et al. (2011) provide a more detailed discussion on the robustness of soil carbon changes for the Amazon region.

Booth and Jones (2011) note that ecosystems will continue to respond to climate change for decades or centuries after climate has stopped changing (Jones et al., 2009). As a result, carbon losses in the short term due to tropical ecosystem loss may be compensated for in the longer term by slower increases in high latitudes (Jones et al., 2010). This also appears to be the case in our simulations and may explain the differences in carbon changes between the A1B and $2 \mathrm{C} 20$ scenario. For example, compared to A1B the smaller total carbon loss over the Amazon under the 2C20 stabilisation scenario is balanced against the stronger high latitude gain (driven in the short term by enhanced growth, and areal expansion in the longer term - Jones et al., 2010) resulting in an overall global gain in contrast to the global loss under A1B.

\subsection{Impacts of vegetation change on future climate}

Although there are few directly comparable studies to ours, qualitative comparisons can be made with relevant globaland regional-scale studies. In general, the impacts of vegetation change on future annual global climate in our study were small, particularly for the biophysical aspects. In addition, the strongest impacts were generally located in the regions of strongest vegetation change, with little evidence of impacts over broader areas. This is perhaps not surprising since the area changes in vegetation in our study were small by comparison to those in other studies.

Strengers et al. (2010) assessed 20th century global climate-vegetation feedbacks using a coupled vegetationclimate model (not including a coupled carbon cycle). In agreement with our findings, anthropogenic land use change had a stronger effect on climate than natural vegetation responses, although the extent of natural vegetation changes over the 20th century was small in comparison to our projected future changes and those of Scholze et al. (2006) and Sitch et al. (2008). In the study of Strengers et al. (2012), albedo was found to be an important driver, although evapotranspiration and cloud formation were equally important especially in the tropics. In their natural vegetation experiments, small changes in tree cover (mainly increases) led to reductions in albedo and increases in temperature, particularly over Siberia.

Jiang et al. (2011) used an atmosphere GCM (AGCM) and a coupled AGCM-terrestrial (equilibrium) biosphere model driven by an ensemble of AR4 model outputs under the A2 scenario to assess the impact of future vegetation change 
on global climate. Key differences in their changes in future vegetation distribution include the lack of Amazon forest dieback and stronger tropical forest increases in general. Their study also found a small impact of vegetation on climate change globally, but significant regional impacts. A warming of $0.1-1 \mathrm{~K}$ was found over continental Eurasia east of $60^{\circ} \mathrm{E}$, mainly driven by albedo changes, and there was a reduction in precipitation over the Amazon. However unlike our study, their simulations did not include the impact of $\mathrm{CO}_{2}$ on vegetation stomatal conductance. An additional factor not considered in our study (Strengers et al., 2010; Jiang et al.,2011) may be vegetation down-regulation under elevated $\mathrm{CO}_{2}$ which could reduce photosynthetic activity and leaf area index, increasing evapotranspiration, leading to an additional cooling effect which could reduce the overall warming impact of vegetation change (Bounoua et al., 2010).

The global-scale study of Swann et al. (2011) found that prescribed large-scale afforestation in Northern Hemisphere mid-latitudes $\left(45\right.$ to $\left.60^{\circ} \mathrm{N}\right)$ under the present-day climate warmed the Northern Hemisphere and altered the Hadley circulation leading to a northward displacement of tropical rain bands. In general, they found small impacts of midlatitude afforestation on global temperature and $\mathrm{CO}_{2}$ concentrations, but significant regional impacts, broadly agreeing with our findings. The greatest warming was found in waterlimited regions (in contrast to our findings), and precipitation decreased over the Amazon and increased over the Sahel and Sahara. Equilibrium water vapour content increased over Northern Hemisphere mid-latitudes by $6.9 \%$, enhancing downward longwave radiation, larger than the changes in our simulations. Swann et al. (2011) showed that evapotranspiration increases outweighed precipitation increases in their simulations, indicating significant regional export of water vapour, which was not the case in our simulations. As noted above, vegetation changes in our study were much less extreme, and tree expansion was mainly located north of $45^{\circ} \mathrm{N}$, which may explain the weaker climate changes observed in our simulations. Terrestrial carbon uptake in their study was $270 \mathrm{Pg}$; for comparison our study found an uptake of 38 and $45 \mathrm{Pg} \mathrm{C}$ for the HIGHLAT region under the A1B and $2 \mathrm{C} 20$ simulations respectively, although our estimates additionally include the impact of future climate change and the location and extent of change also differ. In Swann et al. (2011), the additional warming from vegetation change caused a loss of soil carbon at high latitudes (and elsewhere). We also found a loss of soil carbon and high latitudes under A1B but a small gain under 2C20, although our assessments additionally include future climate drivers. Overall, Swann et al. (2011) estimated that biogeochemical and biophysical feedbacks led to changes in global temperature of -0.4 to $0.1^{\circ} \mathrm{C}$.

Swann et al. (2010) investigated the regional impact of prescribed afforestation with deciduous trees at Northern Hemisphere high latitudes, finding that the top-ofatmosphere radiative imbalance from enhanced transpira- tion was up to 1.5 times greater than the albedo forcing. In their study, greenhouse warming from increases in atmospheric water vapour content melted sea ice, triggering a positive feedback via ocean albedo and evaporation. In our simulations, expansion of the needleleaf tree PFT was more widespread geographically than that of broadleaf trees, with increases of $2-3 \%$ in fractional coverage of the HIGHLAT area for both types. In addition, our climate-driven increases in forest area were much more modest than those of Swann et al. (2010). When fully leafed out, broadleaf trees have twice the albedo and 50-80\% greater evapotranspiration rates than needleleaf trees (Swann et al., 2010), which, in combination with the less extreme afforestation rate, may explain the much weaker change in evapotranspiration in our simulations. In addition, larger impacts on vegetation distribution may be anticipated following a longer period of adjustment to the new climate (Jones et al., 2009, 2010; Booth and Jones, 2011), so potentially larger impacts on evapotranspiration may occur in the longer term. Our simulations also considered future, rather than present climate as in the experiments of Swann et al. (2010) and used different models, which will further alter our results.

Wramneby et al. (2010) used a regional climate model coupled to a DGVM to assess the impacts of changing vegetation patterns on future climate over Europe. Impacts were categorized into three "hotspots": the Scandinavian mountains where reduced albedo from snow masking enhanced DJF warming; Central Europe where a negative evapotranspiration feedback via stimulation of photosynthesis and plant growth due to elevated $\mathrm{CO}_{2}$ concentrations mitigated warming; and southern Europe where increased dryness during JJA reduced plant growth, reducing evapotranspiration and leading to a positive (warming) feedback. They found climate feedbacks over Europe to be small compared to the radiative forcing of increased $\mathrm{CO}_{2}$ concentrations, but noted significant local, regional and seasonal effects. Although the patterns of DJF warming (and albedo change) found in our simulations were similar to those of Wramneby et al. (2010), we found warming in JJA across most of Europe in contrast to the cooling found in their study for Central and Northern Europe.

Kuhry (2010) reports ECHAM5-MPI/OM-JSBACH simulations which applied the vegetation changes from our HadCM3C simulations, but only changing vegetation patterns for the CARBO-North project study region of northeastern European Russia while all other land points were kept constant. Temperature increases of approximately $0.3 \mathrm{~K}$ per decade were found for most of the Arctic, whereas in the region where vegetation actually was changed, the temperature trend was roughly twice as large. This implies that the transition from tundra to taiga in the pan-Arctic domain has wider implications at least for the Northern Hemisphere and may additionally enhance the temperature increase by almost $20 \%$. This result corroborates findings by Dethloff et 
al. (2006), who found a large sensitivity over large parts of the Northern Hemisphere to slight changes in the albedo.

There is significant uncertainty in the impact of vegetation change on future climate. Potential sources of uncertainty include the following: uncertainties in future land use patterns (and how they interact with natural vegetation); differing vegetation model responses to future climate, uncertainties in future projected climate itself (Friedlingstein et al., 2006; Scholze et al., 2006; Denman et al., 2007; Fischlin et al., 2007; Sitch et al., 2008), and resulting uncertainties in biophysical and biogeochemical impacts on climate. In the latter sense, recent assessments of the impact of contemporary anthropogenic land cover change have found considerable variation in responses across models (Pitman et al., 2009; De Noblet-Ducoudre et al., 2012).

\subsection{Implications for climate mitigation and adaptation}

In our simulations, the effect of climate mitigation can be assessed by comparing changes under the $2 \mathrm{C} 20$ and A1B scenarios. For instance, comparing the INTVEG simulations, mitigation avoided over $2 \mathrm{~K}$ of warming relative to preindustrial climate (over $40 \%$ of the unmitigated increase), with almost twice this impact regionally. In contrast, because of the relatively strong reduction in sulphate aerosol concentrations, mitigation had a small impact on global precipitation trends resulting in a relatively strong increase.

Climate mitigation generally led to smaller gains in high latitude tree cover on the one hand, but a smaller loss of the Amazon forest on the other. Mitigation reduced the global loss of terrestrial carbon (mainly due to soil effects). As noted previously, mitigation reduced the total carbon loss over the Amazon which was balanced against the stronger high latitude increase resulting in an overall global gain in contrast to the global loss under business-as-usual. By 2100, high latitude total carbon gains were similar under both scenarios, but still changing, with the loss from soil generally outweighing the gain in vegetation storage. This was presumably because the greater warming under the A1B scenario benefits high latitude vegetation growth but also increases decomposition losses from soils. Overall, this results in a smaller declining trend in total carbon globally (and for high latitudes) under the climate stabilisation scenario at the end of the 21 st Century.

Mitigation generally moderated the impact of vegetation change on future global and regional climate - for instance, by acting to reduce the (global and Amazon) decline in albedo, and reduce the increase in temperature. In addition, while the reduction in evaporation over the Amazon was reduced, the increase over high latitudes was stronger. However, the uncertainties in future carbon stocks and climate response to vegetation changes discussed in Sects. 4.2 and 4.3 make providing a robust alteration to mitigation advice challenging.

\section{Conclusions}

Key shifts in vegetation type in our simulations included increases in needleleaf and broadleaf tree cover over high latitudes, loss of broadleaf tree cover over the Amazon and replacement with $\mathrm{C} 4$ grass, and losses of $\mathrm{C} 3$ grass in high latitudes with replacement by shrubs, particularly over eastern Siberia. A small overall increase in total terrestrial carbon storage was found in our $2 \mathrm{C} 20$ simulation, in contrast to the decrease found for A1B, with much of the difference being driven by changes in soil carbon. Regionally, total carbon storage was reduced over the Amazon and increased over high latitudes. Relative to A1B, $2 \mathrm{C} 20$ reduced the total carbon loss over the Amazon, but amplified the carbon gain over high latitudes. Since carbon storage did not change in our simulations with fixed vegetation, these changes represent the impact of interactive vegetation on carbon storage. Globally, and over high latitudes, interactive vegetation amplified reductions in albedo and increases in albedo over the Amazon, with smaller impacts under 2C20 than under A1B.

Relatively small global impacts of interactive vegetation on most annual mean surface climate variables were found under both $\mathrm{A} 1 \mathrm{~B}$ and $2 \mathrm{C} 20$, with generally smaller impacts under $2 \mathrm{C} 20$. For instance, the slight increase in global mean temperature found under A1B $(0.24 \mathrm{~K})$ was greatly reduced under $2 \mathrm{C} 20(0.15 \mathrm{~K})$. Larger impacts were observed regionally and seasonally and over land. For instance, additional warming of $\sim 1 \mathrm{~K}$ was found over Siberia and over the Amazon under A1B, with smaller changes under 2C20; over landonly grid points, global temperature changes due to interactive vegetation were 0.43 and $0.28 \mathrm{~K}$ under $\mathrm{A} 1 \mathrm{~B}$ and $2 \mathrm{C} 20$, respectively.

The main regional impact of interactive vegetation change on precipitation was the strong reduction found over the Amazon (under A1B), which was much smaller under 2C20. Precipitation changes due to interactive vegetation changes were mostly dominated by changes in convective precipitation. Under A1B, some small increases in evaporation were found over high latitudes and the western Amazon, with reductions over the eastern Amazon, with much smaller impacts under $2 \mathrm{C} 20$ (and no widespread reduction over the eastern Amazon). Over the Amazon, the warming influence of vegetation change in our simulations was driven by the loss of tree cover and increase in bare soil, which led to a reduction in (JJA) evaporation (and latent heat flux), offsetting the slight increase in albedo. As discussed by Cox et al. (2004), in our simulations while grasses did initially expand to cover the area where tree cover was lost, the warming and drying were eventually too intense for even $\mathrm{C} 4$ grasses leading to replacement by bare soil. At high latitudes, warming due to vegetation change resulted from increasing vegetation cover (grasses, trees and shrubs), where the reduced albedo (particularly during DJF and MAM) appears to have offset any small evaporation increases. 
Climate mitigation generally reduced the impact of vegetation change on future global and regional climate in our simulations. Our study therefore suggests that there is a need to consider both changes in the future land carbon cycle (due to their impact on climate) and vegetation changes (since they will also affect climate via both biogeochemical and biophysical effects) in climate adaptation and mitigation decision making. While the impacts of vegetation change on future climate are relatively small globally, larger impacts may result at local to regional scales and on seasonal timescales with implications for adaptation planning. In addition since encouraging forestation and avoiding deforestation form part of the current portfolio of climate mitigation measures, there is a need to better understand future climate vulnerabilities (or opportunities) for forests and land carbon sinks in order to avoid unintended consequences and risks.

\section{Supplementary material related to this article is available online at: http://www.biogeosciences.net/9/ 4739/2012/bg-9-4739-2012-supplement.pdf.}

Acknowledgements. The role of PF, CJ, BB, RD, RB, and HL was supported by the Joint DECC/Defra Met Office Hadley Centre Climate Programme (GA01101) and the European Union project "CARBO-North - Quantifying the carbon budget in Northern Russia: past, present and future", project number 036993. The authors would like to thank the Editor Christoph Spirig, and two anonymous reviewers of the original manuscript, whose comments greatly improved the paper.

Edited by: C. Spirig

\section{References}

Adler, R. F., Huffman, G. J., Chang, A., Ferraro, R., Xie, P., Janowiak, J., Rudolf, B., Schneider, U., Curtis, S., Bolvin, D., Gruber, A., Susskind, J., and Arkin, P.: The Version 2 Global Precipitation Climatology Project (GPCP) Monthly Precipitation Analysis (1979-Present), J. Hydrometeorol., 4, 1147-1167, 2003.

Betts, R. A.: Self-beneficial effects of vegetation on climate in a General Circulation Model, Geophys. Res. Lett., 26, 1457-1460, 1999.

Betts, R. A.: Offset of the potential carbon sink from boreal forestation by decreases in surface albedo, Nature, 408, 187-190, 2000.

Betts, R. A.: Biogeophysical impacts of land use on present-day climate: near-surface temperature change and radiative forcing, Atmos. Sci. Lett., 2, 39-51, doi:1006/asle.2001.0023, 2001.

Betts, R.: Integrated approaches to climate-crop modelling: needs and challenges, Philos. T. Roy. Soc. B, 360, 2049-2065, doi:10.1098/rstb.2005.1739, 2005.

Betts, R. A. , Cox, P. M. , Lee, S. E., and Woodward, F. I.: Contrasting physiological and structural vegetation feedbacks in climate change simulations, Nature, 387, 796-799, 1997.

Betts, R. A., Cox, P. M., Collins, M., Harris, P. P., Huntingford, C., and Jones, C. D.: The role of ecosystem-atmosphere interac- tions in simulated Amazonian precipitation decrease and forest dieback under global climate warming, Theor. Appl. Climatol., 78, 157-175, 2004.

Betts, R., Falloon, P., Klein Goldewijk, K., and Ramankutty, N.: Biogeophysical effects of land use on climate: model simulations of radiative forcing and large-scale temperature change, Agr. Forest Meteorol., 142, 216-233, 2007.

Bonan, G. B., Pollard, D., and Thompson, S. L.: Effects of boreal forest vegetation on global climate, Nature, 359, 716-718, 1992.

Booth, B. B. B. and Jones, C. D.: Terrestrial response of QUMPC ensemble: Hadley Centre Technical Note 89, Met Office Hadley Centre, Exeter, UK, 2011.

Booth, B. B. B, Jones, C. D., Collins, M., Totterdell, I. J., Cox, P. M., Sitch, S., Huntingford, C., Betts, R. A., Harris, G. R., and Lloyd, J: High sensitivity of future global warming to land carbon cycle processes, Env. Res. Lett., 7, 024002, doi:10.1088/17489326/7/2/024002, 2012.

Bounoua, L., DeFries, R., Collatz, G. J., Sellers, P., and Khan, H.: Effects of land cover conversion on surface climate, Climatic Change, 52, 29-64, 2002.

Brasseur, G. P. and Roeckner, E.: Impact of improved air quality on the future evolution of climate, Geophys. Res. Lett., 32, L23704, doi:10.1029/2005GL023902, 2005.

Burke, E. J., Hartley, I. P., and Jones, C. D.: Uncertainties in the global temperature change caused by carbon release from permafrost thawing, The Cryosphere, 6, 1063-1076, doi:10.5194/tc6-1063-2012, 2012.

Collatz, G. J. , Ball, J. T. , Grivet, C., and Berry, J. A.: Physiological and environmental regulation of stomatal conductance, photosynthesis and transpiration: a model that includes a laminar boundary layer, Agr. Forest Meteorol., 54, 107-136, 1991.

Collatz, G. J., Ribas-Carbo, M., and Berry, J. A.: A coupled photosynthesis-stomatal conductance model for leaves of $\mathrm{C} 4$ plants, Aust. J. Plant Physiol., 19, 519-538, 1992.

Collins, M., Tett, S. F. B., and Cooper, C.: The internal climate variability of HadCM3, a version of the Hadley Centre coupled model without flux adjustments, Clim. Dynam., 17, 61-81, 2001.

Collins, M., Booth, B. B. B., Harris, G. R., Murphy, J. M., Sexton D. M. H., and Webb, M. J. : Towards Quantifying Uncertainty in Transient Climate Change, Clim. Dynam., 27, 127-147, 2006.

Collins, W. J., Bellouin, N., Doutriaux-Boucher, M., Gedney, N., Halloran, P., Hinton, T., Hughes, J., Jones, C. D., Joshi, M., Liddicoat, S., Martin, G., O’Connor, F., Rae, J., Senior, C., Sitch, S., Totterdell, I., Wiltshire, A., and Woodward, S.: Development and evaluation of an Earth-System model - HadGEM2, Geosci. Model Dev., 4, 1051-1075, doi:10.5194/gmd-4-10512011, 2011.

Cowling, S. A., Jones, C. D., and Cox, P. M.: Greening the terrestrial biosphere: simulated feedbacks on atmospheric heat and energy circulation, Clim. Dynam., 32, 287-299, 2009.

Cox, P. M.: Description of the TRIFFID dynamic global vegetation model, Hadley Centre Technical Note 24, Hadley Centre, Met Office, UK, 2001.

Cox, P. M., Huntingford, C., and Harding, R. J. A.: A canopy conductance and photosynthesis model for use in a GCM land surface scheme, J. Hydrol., 212-213, 79-94, 1998.

Cox, P. M., Betts, R. A., Bunton, C. B., Essery, R. L. H., Rowntree, P. R., and Smith, J. : The impact of new land surface physics on the GCM simulation of climate and climate sensitivity, Clim. 
Dynam., 15, 183-203, 1999.

Cox, P. M., Betts, R. A., Jones, C. D., Spall, S. A., and Totterdell, I.: Acceleration of global warming due to carbon cycle feedbacks in a coupled climate model, Nature, 408, 184-187, 2000.

Cox, P. M., Betts, R. A., Collins, M., Harris, P. P., Huntingford, C., and Jones, C. D.: Amazonian forest dieback under climatecarbon cycle projections for the 21st century, Theor. Appl. Climatol., 78, 137-156, 2004.

Davin, E. L. and de Noblet-Ducoudré, N.: Climatic impact of global-scale deforestation: radiative versus non-radiative processes, J. Climate, 23, 97-112, doi:10.1175/2009JCLI3102.1, 2010.

de Noblet-Ducoudré, N., Boisier, J.-P., Pitman, A. J., Bonan, G. B. Brovkin, V., Cruz, F., Delire, C. Gayler, V., van den Hurk, B. J. J. M., Lawrence, P. J., van der Molen, M. K., Müller, C., Reick, C. H., Strengers, B. J., and Voldoire, A.: Determining robust impacts of land-use induced land-cover changes on surface climate over North America and Eurasia; Results from the first set of LUCID experiments, J. Climate, 25, 3261-3281, doi:10.1175/JCLID-11-00338.1, 2012.

Denman, K. L., Brasseur, G., Chidthaisong, A., Ciais, P., Cox, P. M., Dickinson, R. E., Hauglustaine, D., Heinze, C., Holland, E., Jacob, D., Lohmann, U., Ramachandran, S., da Silva Dias, P. L., Wofsy, S. C., and Zhang, X.: Couplings Between Changes in the Climate System and Biogeochemistry, In: Climate Change 2007: The Physical Science Basis. Contribution of Working Group I to the Fourth Assessment Report of the Intergovernmental Panel on Climate Change, edited by: Solomon, S., Qin, D., Manning, M., Chen, Z., Marquis, M., Averyt, M. B., Tignor, M., and Miller, H. L., Cambridge University Press, Cambridge, United Kingdom and New York, NY, USA, 2007.

Desjardins, R. L., Sivakumar, M. V. K., de Kimpe, C.: The contribution of agriculture to the state of climate: workshop summary and recommendations, Agr. Forest Meteorol., 2-4, 314-24, 2007.

Dethloff, K., Rinke, A., Benkel, A., Køltzow, M., Sokolova, E., Kumar Saha, S., Handorf, D., Dorn, W., Rockel, B., Von Storch, H., Haugen, J.E., Ried, L. P., Roeckner, E., Christensen, J. H., and Stendel, M.: A dynamical link between the Arctic and the global climate system, Geophys. Res. Lett., 33, L03703, doi:10.1029/2005GL025245, 2006.

Devaraju, N., Cao, L., Bala, G., Caldeira, K., and Nemani, R.: A model investigation of vegetation-atmosphere interactions on a millennial timescale, Biogeosciences, 8, 3677-3686, doi:10.5194/bg-8-3677-2011, 2011.

Douville, H. and Royer, J.-F.: Influence of the temperate and boreal forests on the Northern Hemisphere climate in the Meteo-France climate model, Clim. Dynam., 13, 57-74, 1997.

Essery, R., Best, M., and Cox, P.: MOSES 2.2 technical documentation. Hadley Centre Technical Note 30, Met Office Hadley Centre, Exeter, UK, 31 pp., available at: http://www.metoffice.gov. uk/archive/hadley-centre-technical-note-30, 2001.

Essery, R. L. H., Best, M. J., Betts, R. A., Cox, P. M., and Taylor, C. M.: Explicit representation of subgrid heterogeneity in a GCM land-surface scheme, J. Hydrometeorol., 4, 530-543, 2003.

Falloon, P. and Betts, R.: The impact of land use change on climate in HadGEM1 simulations, Defra Milestone 04/07 13.01.06, Physical, chemical, biological effects of climate change, Met Office Hadley Centre, Exeter, UK, 2006.
Falloon, P. D., Jones, C. D., Ades, M., and Paul, K.: Direct soil moisture controls of future global soil carbon changes ; an important source of uncertainty. Global Biogeochem. Cy., 25, GB3010, doi:10.1029/2010GB003938, 2011.

Falloon, P. D., Dankers, R., Betts, R. A., Jones, C. D., Booth, B. B. B., and Lambert, F. H.: Role of vegetation change in future climate under the A1B scenario and a climate stabilisation scenario, using the HadCM3C earth system model, Biogeosciences Discuss., 9, 7601-7659, doi:10.5194/bgd-9-7601-2012, 2012.

Feddema, J. J., Oleson, K. W., Bonan, G. B., Mearns, L. O., Buja, L. E., Meehl, G. A., and Washington, W. M.: The importance of land cover change in simulating future climates, Science, 310, 1674-1678, 2001

Feichter, J., Roeckner, E., Lohmann, U., and Liepert, B.: Nonlinear aspects of the climate response to greenhouse gas and aerosol forcing, J. Climate, 17, 2384-2398, 2004.

Fischlin, A., Midgley, G. F., Price, J. T., Leemans, R., Gopal, B., Turley, C., Rounsevell, M. D. A., Dube, O. P., Tarazona, J., and Velichko, A. A.: Ecosystems, their properties, goods, and services. Climate Change 2007: Impacts, Adaptation and Vulnerability. Contribution of Working Group II to the Fourth Assessment Report of the Intergovernmental Panel on Climate Change, edited by: Parry, M. L., Canziani, O. F., Palutikof, J. P., van der Linden P. J., and Hanson, C. E., Cambridge University Press, Cambridge, 211-272, 2007.

Foley, J. A., Kutzbach, J., Coe, M. T., and Levis, S.: Feedbacks between climate and boreal forests during the holocene epoch, Nature, 371, 52-54, 1994.

Friedlingstein, P., Cox, P., Betts, R., Bopp, L., von Bloh, W. Brovkin, V., Doney, S., Eby, M., Fung, I., Govindasamy, B., John, J. Jones, C., Joos, F., Kato, T., Kawamiya, M., Knorr, W., Lindsay, K., Matthews, H. D., Raddatz, T., Rayner, P., Reick, C., Roeckner, E., Schnitzler, K. G., Schnur, R., Strassmann, K., Thompson, S., Weaver, A. J., Yoshikawa, C., and Zeng, N.: Climate-carbon cycle feedback analysis, results from the C4MIP model inter-comparison, J. Climate, 19, 3337-3353, 2006.

Gordon, C., Cooper, C., Senior, C. A., Banks, H., Gregory, J. M., Johns, T. C., Mitchell J. F. B., and Wood, R. A.: The simulation of SST, sea ice extents and ocean heat transport in a version of the Hadley Centre coupled model without flux adjustments, Clim. Dynam., 16, 147-168, 2000

Hawkins, E. and Sutton, R. T.: The potential to narrow uncertainty in projections of regional precipitation change, Clim. Dyn., 37, 407-418, doi:10.1007/s00382-010-0810-6, 2011.

Held, I. M. and Soden, B. J.: Robust responses of the hydrological cycle to global warming, J. Climate, 19, 5686-5699, doi:10.1175/JCLI3990.1, 2006.

Hurtt, G. C., Chini, L. P., Frolking, S., Betts, R., Feedema, J., Fischer, G., Hibbard, K., Houghton, R., Janetos, A., Jones, C., Kindermann, G., Kinoshita, T., Klein Goldewijk, K., Riahi, K., Shevliakova, E., Smith, S., Stehfest, E., Thomson, A., Thornton, P., van Vuuren, D., and Wang, Y.: Harmonization of Land-Use Scenarios for the Period 1500-2100: 600 Years of Global Gridded Annual Land-Use Transitions, Wood Harvest, and Resulting Secondary Lands, Climatic Change, 109, 117161, doi:10.1007/s10584-011-0153-2, 2011.

Jiang, D., Zhang, Y., and Lang, X.: Vegetation feedback under future global warming, Theor. Appl. Climatol., 106, 211-227, 2011. 
Johns, T. C., Gregory, J. M., Ingram, W. I., Johnson, C. E., Jones, A., Lowe, J. A., Mitchell, J. F. B., Roberts, D. L., Sexton, D. M. H., Stevenson, D. S., Tett, S. F. B., and Woodage, M. J.; Anthropogenic climate change for 1860 to 2100 simulated with the HadCM3 model under updated emissions scenarios, Clim. Dynam., 20, 583-612, 2003.

Johns, T. C., Durman, C. F., Banks, H. T., Roberts, M. J., McLaren, A. J., Ridley, J. K., Senior, C. A., Williams, K. D., Jones, A., Rickard, G. J., Cusack, S., Ingram, W. J., Crucifix, M., Sexton, D. M. H., Joshi, M. M., Dong, B. W., Spencer, H., Hill, R. S. R., Gregory, J. M., Keen, A. B., Pardaens, A. K., Lowe, J. A., Bodas-Salcedo, A., Stark, S., and Searl, Y.: The new Hadley Centre climate model HadGEM1: evaluation of coupled simulations, J. Climate, 19, 1327-1353, 2006.

Jones, A., Roberts, D. L., Woodage, M. J., and Johnson, C. E.: Indirect sulphate aerosol forcing in a climate model with an interactive sulphur cycle, J. Geophys. Res., 106, 20293-20310, doi:10.1029/2000JD000089, 2001.

Jones, C. D., Cox, P. M., Essery, R. L. H., Roberts, D. L., and Woodage, M. J.: Strong carbon cycle feedbacks in a climate model with interactive $\mathrm{CO}_{2}$ and sulphate aerosols, Geophys. Res. Lett., 30, 1479, doi:10.1029/2003GL016867, 2003.

Jones, C. D., McConnell, C., Coleman, K. W., Cox, P., Falloon, P. D., Jenkinson, D., and Powlson, D. S.: Global climate change and soil carbon stocks; predictions from two contrasting models for the turnover of organic carbon in soil, Glob. Change Biol., 11, 154-166, 2005.

Jones, C., Lowe, J., Liddicoat, S., and Betts, R.: Committed terrestrial ecosystem changes due to climate change, Nat. Geosci., 2, 484-487, 2009.

Jones, C. D., Liddicoat, S., And Lowe, J.: Role of terrestrial ecosystems in determining $\mathrm{CO}_{2}$ stabilization and recovery behaviour, Tellus B, 62, 682-699, 2010.

Jones, C. D., Hughes, J. K., Bellouin, N., Hardiman, S. C., Jones, G. S., Knight, J., Liddicoat, S., O’Connor, F. M., Andres, R. J., Bell, C., Boo, K.-O., Bozzo, A., Butchart, N., Cadule, P., Corbin, K. D., Doutriaux-Boucher, M., Friedlingstein, P., Gornall, J., Gray, L., Halloran, P. R., Hurtt, G., Ingram, W. J., Lamarque, J.-F., Law, R. M., Meinshausen, M., Osprey, S., Palin, E. J., Parsons Chini, L., Raddatz, T., Sanderson, M. G., Sellar, A. A., Schurer, A., Valdes, P., Wood, N., Woodward, S., Yoshioka, M., and Zerroukat, M.: The HadGEM2-ES implementation of CMIP5 centennial simulations, Geosci. Model Dev., 4, 543-570, doi:10.5194/gmd-4-543-2011, 2011.

Kuhry, P. (Ed.): CARBO-North: : Quantifying the carbon budget in Northern Russia: past, present and future, EU Contract no: 036993, 4th periodic activity report, July 30th 2010, Stockholm University, Stockholm, 2010.

Lawrence, D. M. and Swenson, S. C.: Permafrost response to increasing arctic shrub abundance depends on the relative influence of shrubs on local soil cooling versus large-scale climate warming, Environ. Res. Lett., 6, 045504, doi:10.1088/17489326/6/4/045504, 2011.

Lean, J. and Warrilow, D. A.: Simulation of the regional climatic impact of Amazon deforestation, Nature, 342, 411-413, 1989.

Lee, X., Goulden, M. L., Hollinger, D. Y., Barr, A., Black, T. A., Bohrer, G., Bracho, R., Drake, B., Goldstein, A., Gu, L., Katul, G., Kolb, T., Law, B. E., Margolis, H., Meyers, T., Monson, R., Munger, W., Oren, R., Paw U, K. T., Richardson, A. D., Schmid,
H. P., Staebler, R., Wofsy, S., and Zhao, L.: Observed increase in local cooling effect of deforestation at higher latitudes, Nature, 479, 384-387, 2011.

Malhi, Y., Aragão, L. E. O. C., Galbraith, D., Huntingford, C., Fisher, R., Zelazowski, P., Sitch, S., McSweeney, C., and Meir, P.: Tipping elements in Earth systems special feature: Exploring the likelihood and mechanism of a climate-change-induced dieback of the Amazon rainforest, P. Natl. Acad. Sci. USA, 106, 20610-20615, doi:10.1073/pnas.0804619106, 2009.

Martin, G. M., Ringer, M. A., Pope, V. D., Jones, A., Dearden, C., and Hinton, T. J.: The physical properties of the atmosphere in the new Hadley Centre Global Environmental Model, HadGEM1. Part 1: Model description and global climatology, J. Climate, 19, 1274-1301, 2006.

May, W.: Climate changes associated with a global "2 Cstabilization" scenario simulated by the ECHAM57MPI-OM coupled climate model, Clim. Dynam., 31, 283-313, 2008.

McCarthy, M. P., Sanjay, J., Booth, B. B. B., Krishna Kumar, K., and Betts, R. A.: The influence of vegetation on the ITCZ and South Asian monsoon in HadCM3, Earth Syst. Dynam., 3, 8796, doi:10.5194/esd-3-87-2012, 2012.

McGuire, A. D., Melillo, J. M., Joyce, L. A., Kicklighter, D. W., Grace, A. L., Moore III, B., and Vorosmarty, C. J.: Interactions between carbon and nitrogen dynamics in estimating net primary productivity for potential vegetation in North America, Global Biogeochem. Cy., 6, 101-124, doi:10.1029/92GB00219, 1992.

Meehl, G. A., Stocker, T. F., Collins, W. D., Friedlingstein, P., Gaye, A. T., Gregory, J. M., Kitoh, A., Knutti, R., Murphy, J. M., Noda, A., Raper, S. C. B., Watterson, I. G., Weaver, A. J., and Zhao, Z.-C. : Global climate projections, in: Climate Change 2007: The Physical Science Basis. Contribution of Working Group I to the Fourth Assessment Report of the Intergovernmental Panel on Climate Change, edited by: Solomon, S., Qin, D., Manning, M., Chen, Z., Marquis, M., Averyt, K. B., Tignor, M., and Miller, H. L., Cambridge University Press, Cambridge, 747-846, 2007.

Murphy, J., Sexton, D., Jenkins, G., Boorman, P., Booth, B., Brown, K., Clark, R., Collins, M., Harris, G., and Kendon, E.: UK Climate Projections science report: Climate Change Projections, Met Office Hadley Centre, Exeter, UK, 2009.

Nakićenović, N., Alcamo, J., Davis, G., de Vries, B., Fenhann, J., Gaffin, S., Gregory, K., Grübler, A., Jung, T. Y., Kram, T., Lebre la Rovere, E., Michaelis, L., Mori, S., Morita, T., Pepper, W., Pitcher, H., Price, L., Riahi, K., Roehrl, A., Rogner, H. H., Sankovski, A., Schlesinger, M., Shukla, P., Smith, S., Swart, R., van Rooijen, S., Victor, N., and Dadi, Z. (Eds.): Emissions Scenarios: A Special Report of the Intergovernmental Panel on Climate Change (IPCC), Cambridge University Press, Cambridge, 2000.

New, M., Hulme, M., and Jones, P.: Representing twentieth century space-time climate variability, Part I: Development of a 1961-90 mean monthly terrestrial climatology, J. Climate, 12, 829-856, 1999.

Palmer, J. R. and Totterdell, I. J.: Production and export in a global ocean ecosystem model, Deep Sea Res. Pt. I, 48, 1169-1198, 2001.

Pacifico, F., Harrison, S. P., Jones, C. D., Arneth, A., Sitch, S., Weedon, G. P., Barkley, M. P., Palmer, P. I., Serça, D., Potosnak, M., $\mathrm{Fu}$, T.-M., Goldstein, A., Bai, J., and Schurgers, G.: Evaluation of a photosynthesis-based biogenic isoprene emission scheme 
in JULES and simulation of isoprene emissions under presentday climate conditions, Atmos. Chem. Phys., 11, 4371-4389, doi:10.5194/acp-11-4371-2011, 2011.

Pardaens, A. K., Banks, H. T., Gregory, J. M., and Rowntree, P. R.: Freshwater transports in HadCM3, Clim. Dynam., 21, 177-195, 2003.

Paustian, K., Ravindranath, N. H., van Amstel, A., Gytarsky, M., Kurz, W. A., Ogle, S., Richards, G., and Somogyi, Z.: Introduction, in: IPCC 2006, 2006 IPCC Guidelines for National Greenhouse Gas Inventories, Prepared by the National Greenhouse Gas Inventories Programme, edited by: Eggleston, H. S., Buendia, L., Miwa, K., Ngara, T., and Tanabe, K., IGES, Japan, 2006.

Pielke, R. A., Avissar, R., Raupach, M., Dolman, A. J., Zeng X., and Denning, A. S.: Interaction between the atmosphere and terrestrial ecosystems: influence on weather and climate, Glob. Change Biol., 4, 461-475, 1998.

Pitman, A. J., de Noblet-Ducoudré, N., Cruz, F. T., Davin, E. L., Bonan, G. B., Brovkin, V., Claussen, M., Delire, C., Ganzeveld, L., Gayler, V., van den Hurk, B. J. J. M., Lawrence, P. J., van der Molen, M. K., Müller, C., Reick, C. H., Seneviratne, S. I., Strengers, B. J., and Voldoire, A.: Uncertainties in climate responses to past land cover change: First results from the LUCID intercomparison study, Geophys. Res. Lett., 36, L14814, doi:10.1029/2009GL039076, 2009.

Pongratz, J., Reick, C. H., Raddatz, T., and Claussen, M.: Biogeophysical versus biogeochemical climate response to historical anthropogenic land cover change, Geophys. Res. Lett., 37, L08702, doi:10.1029/2010GL043010, 2010.

Qian, H., Joseph, R., and Zeng, N.: Enhanced terrestrial carbon uptake in the northern high latitudes in the 21 st century from the coupled carbon cycle climate model intercomparison project model projections, Glob. Change Biol., 16, 641-656, 2010.

Raddatz, R. L.: Evidence for the influence of agriculture on weather and climate through the transformation and management of vegetation: illustrated by examples from the Canadian Prairies, Agr. Forest Meteorol., 142, 186-202, 2007.

Ramankutty, N. and Foley, J. A.; Estimating historical changes in global land cover: croplands from 1700 to 1992, Global Biogeochem. Cy., 13, 997-1027, 1999.

Raich, J. and Schlesinger, W.: The global carbon dioxide flux in soil respiration and its relationship to vegetation and climate, Tellus B, 44, 81-99, 1992.

Scholze, M., Knorr, W., Arnell, N. W., and Prentice, I. C.: A climate-change risk analysis for world ecosystems, P. Natl. Acad. Sci. USA, 103, 13116-13120, doi:10.1073/pnas.0601816103, 2006.
Sitch, S., Huntingford, C., Gedney, N., Levy, P. E., Lomas, M., Piao, S. L., Betts, R., Ciais, P., Cox, P., Friedlingstein, P., Jones, C. D., Prentice, I. C., and Woodward, F. I.: Evaluation of the terrestrial carbon cycle, future plant geography and climate-carbon cycle feedbacks using five Dynamic Global Vegetation Models (DGVMs), Glob. Change Biol., 14, 2015-2039, doi:10.1111/j.1365-2486.2008.01626.x, 2008.

Smith, R. N. B., Blyth, E. M., Finch, J. W., Goodchild, S., Hall, R. L., and Madry, S.: Soil state and surface hydrology diagnosis based on MOSES in the Met Office Nimrod nowcasting system, Meteorol. Appl., 13, 89-109, 2006.

Stott, P. A., Jones, G. S., Lowe, J. A., Thorne, P., Durman, C., Johns, T. C., and Thelen, J-C.: Transient Climate Simulations with the HadGEM1 Climate Model: Causes of Past Warming and Future Climate Change, J. Climate, 19, 2763-2782, 2006.

Strengers, B. J., Müller, C., Schaeffer, M., Haarsma, R. J., Severijns, C., Gerten, D., Schaphoff, S., van den Houdt, R., and Oostenrijk, R.: Assessing 20th century climate-vegetation feedbacks of land-use change and natural vegetation dynamics in a fully coupled vegetation-climate model, Int. J. Climatol., 30, 2055-2065. doi:10.1002/joc.2132, 2010.

Swann, A. L., Fung, I. Y., Levis, S., Bonan, G., and Doney, S.: Changes in Arctic vegetation induce high-latitude warming through the greenhouse effect. P. Natl. Acad. Sci. USA, 107, 1295-1300, doi:10.1073/pnas.0913846107, 2010.

Swann, A. L. S., Fung, I. Y., and Chiang, J. C. H.: Mid-latitude afforestation shifts general circulation and tropical precipitation, PNAS, 109, 712-716, doi:10.1073/pnas.1116706108, 2011.

Taylor, K. E., Stouffer, R. J., and Meehl, G. A.: An Overview of CMIP5 and the experiment design, B. Am. Meteor. Soc., 93, 485-498, doi:10.1175/BAMS-D-11-00094.1, 2012.

Thomas, G. and Rowntree, P. R.: The boreal forests and climate, Q. J. R. Meteorol. Soc, 118, 469-497, 1992.

van der Linden, P. and Mitchell, J. F. B. (Eds.): ENSEMBLES: Climate Change and its Impacts: Summary of research and results from the ENSEMBLES project, Met Office Hadley Centre, FitzRoy Road, Exeter EX1 3PB, UK, 2009.

Van Vuuren, D. P., Edmonds, J., Kainuma, M. L. T. , Riahi, K., Thomson, A., Matsui, T., Hurtt, G., Lamarque, J.-F., Meinshausen, M., Smith, S., Grainer, C., Rose, S., Hibbard, K. A., Nakicenovic, N., Krey, V., and Kram, T.: Representative Concentration Pathways: an overview, Climatic Change, 109, 5-39, doi:10.1007/s10584-011-0148-z, 2011.

Wang, S. and Davidson, A.: Impact of climate variations on surface albedo of a temperate grassland, Agr. Forest Meteorol., 2-4, 133-42, 2007.

Wramneby, A., Smith, B., and Samuelsson, P.: Hot spots of vegetation-climate feedbacks under future greenhouse forcing in Europe, J. Geophys. Res., 115, D21119, doi:10.1029/2010JD014307, 2010. 